\title{
Hybrid Closed-Loop Systems for the Treatment of Type 1 Diabetes: A Collaborative, Expert Group Position Statement for Clinical Use in Central and Eastern Europe
}

\author{
Andrej Janez (1) - Tadej Battelino · Tomasz Klupa · Győző Kocsis · Miriam Kuricová · Nebojša Lalić · \\ Anca Pantea Stoian · Martin Prázný · Dario Rahelić · Jan Šoupal · Tsvetalina Tankova · Nataliya Zelinska
}

Received: August 18, 2021 / Accepted: September 18, 2021 / Published online: October 25, 2021

(C) The Author(s) 2021

\section{ABSTRACT}

In both pediatric and adult populations with type 1 diabetes (T1D), technologies such as

\section{A. Janez $(\bowtie)$}

Department of Endocrinology, Diabetes and Metabolic Diseases, University Medical Center Ljubljana, Zaloska 7, 1000 Ljubljana, Slovenia e-mail: andrej.janez@kclj.si

T. Battelino

University Medical Center Ljubljana, Ljubljana, Slovenia

T. Battelino

Faculty of Medicine, University of Ljubljana, Ljubljana, Slovenia

\section{T. Klupa}

Department of Metabolic Diseases, Jagiellonian University Medical College, Krakow, Poland

T. Klupa

University Hospital, Kraków, Poland

G. Kocsis

Department of Medicine and Oncology,

Semmelweis University Budapest, Budapest,

Hungary

M. Kuricová

Pediatric Department, National Institute of

Endocrinology and Diabetology, Lubochňa, Slovakia

M. Kuricová

Department of Children and Adolescents, Jessenius Faculty of Medicine, Comenius University

Bratislava, Martin, Slovakia continuous subcutaneous insulin infusion (CSII), continuous glucose monitoring (CGM), or sensor-augmented pumps (SAP) can consistently improve glycemic control [measured as glycated hemoglobin (HbA1c) and time in

\section{N. Lalić}

Faculty of Medicine of the University of Belgrade, Clinic for Endocrinology, Diabetes and Metabolic Diseases, Clinical Center of Serbia, Belgrade, Serbia

\section{A. P. Stoian}

Department of Diabetes, Nutrition and Metabolic Diseases, Carol Davila University of Medicine and Pharmacy, Bucharest, Romania

\section{Prázný · J. Šoupal}

Third Department of Internal Medicine, First Faculty of Medicine, Charles University and General Faculty Hospital, Prague, Czechia

\section{Rahelić}

Vuk Vrhovac University Clinic for Diabetes, Endocrinology and Metabolic Diseases, Merkur University Hospital, Zagreb, Croatia

D. Rahelić

School of Medicine, University of Zagreb, Zagreb, Croatia

D. Rahelić

School of Medicine, Josip Juraj Strossmayer University of Osijek, Osijek, Croatia

T. Tankova Department of Endocrinology, Medical University of Sofia, Sofia, Bulgaria 
range (TIR)] while reducing the risk of hypoglycemia. Use of technologies can thereby improve quality of life and reduce the burden of diabetes management compared with self-injection of multiple daily insulin doses (MDI). Novel hybrid closed-loop (HCL) systems represent the latest treatment modality for T1D, combining modern glucose sensors and insulin pumps with a linked control algorithm to offer automated insulin delivery in response to blood glucose levels and trends. HCL systems have been associated with increased TIR, improved HbA1c, and fewer hypoglycemic events compared with CSII, SAP, and MDI, thereby potentially improving quality of life for people with diabetes (PwD) while reducing the costs of treating short- and long-term diabetes-related complications. However, many barriers to their use and regional inequalities remain in Central and Eastern Europe (CEE). Published data suggest that access to diabetes technologies is hindered by lack of funding, underdeveloped health technology assessment (HTA) bodies and guidelines, unfamiliarity with novel therapies, and inadequacies in healthcare system capacities. To optimize the use of diabetes technologies in $\mathrm{CEE}$, an international meeting comprising experts in the field of diabetes was held to map the current regional access, to present the current national reimbursement guidelines, and to recommend solutions to overcome uptake barriers. Recommendations included regional and national development of HTA bodies, efficient allocation of resources, and structured education programs for healthcare professionals and PwD. The responsibility of the healthcare community to ensure that all individuals with T1D gain access to modern technologies in a timely and economically responsible manner, thereby improving health outcomes, was emphasized, particularly for interventions that are cost-effective.
Keywords: Advanced hybrid closed-loop; Central and Eastern Europe; Hybrid closedloop; Position statement; Type 1 diabetes

\section{Key Summary Points}

Diabetes technologies can help to improve health outcomes for individuals with type 1 diabetes (T1D) compared with traditional, self-injectable treatments.

However, many barriers remain to their use in Central and Eastern Europe (CEE), including lack of funding, underdeveloped health technology assessment (HTA) bodies and guidelines, unfamiliarity with novel therapies, and inadequacies in healthcare system capacities.

To overcome these barriers, the present position statement recommended the continued regional and national development of HTA bodies, more efficient allocation of resources, and structured education programs for healthcare professionals and people with diabetes.

The expert group wished to emphasize the responsibility of the healthcare community to ensure that all individuals with T1D gain timely access to modern, cost-effective technologies to improve health outcomes while providing value for money for healthcare payers.

The present position statement should be used to inform development of updated guidance in the CEE region for the reimbursement of efficacious diabetes technologies, including novel hybrid closed-loop systems.

N. Zelinska

Ukrainian Scientific and Practical Center of Endocrine Surgery, Transplantation of Endocrine Organs and Tissues of the Ministry of Health of Ukraine, Kyiv, Ukraine 


\section{INTRODUCTION}

Type 1 diabetes (T1D) is a chronic autoimmune disease characterized by loss of pancreatic beta cells and subsequent insulin deficiency. Lifelong intensified insulin treatment is currently the only recommended treatment modality for T1D, with the aim to reduce hyperglycemia and thereby prevent diabetesrelated complications and premature mortality. The disease is associated with a considerable clinical burden, with more than 46 million people affected worldwide and approximately 6 million people estimated to be living with T1D in Europe in 2019 [1]. Healthcare expenditure associated with T1D encompasses both therapy-related costs and treatment of diabetesrelated complications, such as retinopathy, renal failure, neuropathy and foot ulceration, amputation, cardiovascular disease, and stroke, which arise from consistently heightened, uncontrolled blood glucose levels (measured via glycated hemoglobin [HbA1c]) and can influence the likelihood of premature mortality [2-5]. Diabetes-related complications can also have a substantial impact on the quality of life of people with diabetes (PwD) [6-8].

Ensuring consistent glycemic control with blood glucose levels within defined targets is crucial for reducing the incidence of complications, as shown by the landmark Diabetes Control and Complications Trial (DCCT) and the Epidemiology of Diabetes Interventions and Complications (EDIC) study [2-4, 9]. Optimal glucose control therefore remains the key goal of treatment for people with T1D. Improved time in range (TIR) of glycemic targets can also substantially reduce the stress and worry of PwD, thereby improving quality of life [10]. Barriers to efficacious diabetes technologies currently exist in many healthcare systems, which can prevent PwD from reaching glycemic control and thereby cause considerable harm to individuals over the long term, in terms of both health and psychological outcomes. Reimbursement of efficacious treatment options that improve glycemic control can also potentially lead to overall cost savings by reducing both short- and long-term diabetes-related complications and subsequent hospitalizations, medical procedures, and associated pharmacotherapy; indeed, improved glycemic control and absence of diabetes-related complications have been associated with reduced healthcare and societal costs $[11,12]$.

\section{Treatment Modalities for Type 1 Diabetes}

Precise insulin replacement therapy forms the cornerstone of T1D management, and there are many insulin treatment options and delivery methods available for PwD. Self-injection of multiple daily doses of insulin (MDI) represents the most common first-line therapy for people with T1D, with doses manually adjusted on the basis of planned or unplanned daily food intake, physical activity, and current blood glucose levels, which requires regular self-monitoring of blood glucose (SMBG) testing. While self-injection is an affordable insulin delivery mechanism, PwD need to be educated and trained appropriately in self-administration and should be confident enough to adapt doses to common daily activities. However, many individuals fail to consistently achieve target blood glucose levels, with an international study demonstrating that a large proportion of individuals do not achieve an HbA1c target of $7.0 \%$ $(53 \mathrm{mmol} / \mathrm{mol})$, and that approximately $68 \%$ of people with T1D were living with an HbA1c above $7.5 \%$ ( $58 \mathrm{mmol} / \mathrm{mol}$ ) [13]. Hypoglycemia remains a common adverse effect of intensified insulin therapy, and fear of hypoglycemic events is a key factor in adherence to intensified insulin regimens [14-16]. Fear of hypoglycemia is compounded by hypoglycemia unawareness, defined as the onset of neuroglycopenia prior to symptoms or the failure to detect a significant drop below normal blood glucose levels [17]. Hypoglycemia unawareness is common in people with T1D, and can have a substantial impact on morbidity and mortality, with associated complications including bone fractures, joint dislocation, seizure, coma, cardiac arrhythmias, and an increased risk of severe hypoglycemia [18-20]. Both fear of hypoglycemia and hypoglycemia itself can have a substantial impact on quality of life and medical expenditure [21]. As 
perfect self-management is not a reality in most PwD, current T1D therapy is trending towards the broader use of technologies after initial treatment with MDI has proven ineffective (e.g., when not achieving glycemic targets, or experiencing pronounced dawn phenomenon, high glycemic variability, or problematic hypoglycemia).

The idea of a functional "artificial pancreas" was first conceived almost 50 years ago, and this closed-loop system arguably still represents the ultimate goal of treatments for people with T1D [22]. Advancements in diabetes technology have allowed for continuous monitoring of blood glucose and automated administration of insulin subcutaneously, leading to lower rates of and time spent in hypoglycemia and improved TIR. Indeed, real-world data have indicated that both adult and pediatric populations with T1D experienced improved glycemic control with modern diabetes technologies compared with MDI [23, 24]. However, many access barriers remain to their use, particularly in the Central and Eastern European region, where substantial healthcare funding for diabetes technologies is often absent.

\section{Aim}

The aim of this position statement was to summarize the available types of diabetes technologies and outline their clinical use cases, explore barriers to access for these technologies, and outline possible approaches to improving medical care for adult and pediatric populations with T1D in Central and Eastern Europe, as well as providing regional clinical recommendations for hybrid closed-loop (HCL) systems.

\section{Compliance with Ethics Guidelines}

This article is based on previously conducted studies and does not contain any studies with human participants or animals performed by any of the authors.

\section{DIABETES TECHNOLOGIES AND THEIR APPLICATIONS}

The current level of evidence and recommendations for use of modern diabetes technologies are summarized in Table 1.

\section{Continuous Glucose Monitoring and Subcutaneous Insulin Infusion}

Continuous glucose monitoring (CGM) and continuous subcutaneous insulin infusion (CSII) are two diabetes technologies that have revolutionized diabetes care, with both technologies associated with improved HbA1c levels, increased TIR, and fewer hypoglycemic events compared with MDI [23-28].

CGM is achieved through a compact medical device that monitors blood glucose levels in real time, which can send alerts to either a dedicated monitoring device or a smartphone app. CGM thereby reduces the need for frequent SMBG testing (and associated finger-pricking), and is frequently offered to PwD experiencing persistent hyper- or hypoglycemia [29]. The latest guidelines published by the Endocrine Society in the USA recommended use of CGM devices in adult populations with T1D who are willing to utilize the devices on a near-daily basis, irrespective of glycemic control status [30]. Moreover, a 2017 international consensus statement recommended the use of CGM, in combination with regular $\mathrm{HbA1c}$ measurements for glycemic status assessment and subsequent therapy adjustment, in all people with T1D not achieving glycemic targets, particularly when hypoglycemia is a concern [31]. It was indicated that all individuals should receive training on how to interpret and respond to glycemic data, with education utilizing standardized programs with follow-up to improve adherence and ensure appropriate use of data and therapies [31]. The consensus statement also recognized the importance of wearing CGM devices on a neardaily basis to optimize their benefits, and concluded that CGM should be considered to help improve glycemic control, provided that appropriate educational and technical support is available [31]. 
Table 1 Recommendations for use of current diabetes technologies

\begin{tabular}{|c|c|c|}
\hline Technology & Recommendation & $\begin{array}{l}\text { Evidence } \\
\text { level }^{\mathbf{a}}\end{array}$ \\
\hline \multirow[t]{6}{*}{ CSII } & $\begin{array}{l}\text { CSII should be considered as a treatment option for all children and adults with T1D who are } \\
\text { able to safely manage the device }\end{array}$ & A \\
\hline & $\begin{array}{l}\text { A well-trained multidisciplinary specialist team is crucial for safe and effective patient selection, } \\
\text { education, and management }\end{array}$ & A \\
\hline & $\begin{array}{l}\text { Individuals should be adequately educated on CSII use through a comprehensive pump } \\
\text { management education program }\end{array}$ & A \\
\hline & $\begin{array}{l}\text { In people on MDI who are not achieving glycemic targets, CSII with or without CGM may be } \\
\text { used to improve HbAlc }\end{array}$ & B \\
\hline & $\begin{array}{l}\text { CSII with or without CGM may be used instead of MDI to improve treatment satisfaction, } \\
\text { quality of life, and other health-related outcomes }\end{array}$ & $\mathrm{C}$ \\
\hline & Individuals on CSII should undergo periodic evaluation to determine whether CSII is effective & E \\
\hline \multirow[t]{7}{*}{ CGM } & CGM should be considered in children and adults with T1D on CSII or MDI & A \\
\hline & $\begin{array}{l}\text { Real-time CGM with high sensor adherence may be used to improve HbAlc regardless of the } \\
\text { insulin delivery method }\end{array}$ & B \\
\hline & The benefits of CGM correlate with adherence to the ongoing use of the device & B \\
\hline & $\begin{array}{l}\text { CGM in conjunction with MDI can lower HbAlc and reduce hypoglycemia in adults with } \\
\text { T2D who are not meeting glycemic targets }\end{array}$ & B \\
\hline & $\begin{array}{l}\text { CGM may be used in pregnant women with T1D to improve glycemic control and neonatal } \\
\text { outcomes }\end{array}$ & B \\
\hline & $\begin{array}{l}\text { CGM with alarms should be considered in patients with frequent hypoglycemia, previous } \\
\text { hypoglycemic seizures, hypoglycemia unawareness, or when fear of hypoglycemia is high }\end{array}$ & B \\
\hline & $\begin{array}{l}\text { Real-time CGM is preferred in those with frequent hypoglycemic episodes or hypoglycemia } \\
\text { unawareness }\end{array}$ & B \\
\hline \multirow[t]{3}{*}{ SAP } & SAP can be considered in children and adults to improve glycemic control & A \\
\hline & The benefits correlate with adherence to the ongoing use of the system & A \\
\hline & $\begin{array}{l}\text { SAP with automatic low glucose suspend may be considered for patients with T1D at high risk } \\
\text { for hypoglycemia to prevent episodes of hypoglycemia and reduce their severity }\end{array}$ & B \\
\hline
\end{tabular}

$C G M$ continuous glucose monitoring, CSII continuous subcutaneous insulin infusion, $H b A 1 c$ glycated hemoglobin, $M D I$ multiple daily insulin, $S A P$ sensor-augmented pump, TID type 1 diabetes, T2D type 2 diabetes

${ }^{a}$ A grading system developed by the American Diabetes Association was used to classify the evidence that forms the basis for the recommendations. Recommendations are assigned ratings of A (clear evidence from well-conducted, generalizable randomized controlled trials that were adequately powered, including evidence from a meta-analysis that incorporated quality ratings in the analysis); B (evidence from a well-conducted prospective cohort study or registry, or from a wellconducted meta-analysis of cohort studies); or C (evidence from randomized clinical trials with one or more major or three or more minor methodological flaws that could invalidate the results, or from case series or case reports). Expert opinion (E) is a separate category for recommendations in which there is no evidence from clinical trials 
CSII is achieved through devices known as insulin pumps, which provide a readily available and steady administration of insulin subcutaneously, while also allowing the user to instantaneously administer insulin should the need arise to help control blood glucose levels. CSII also relieves the user of the majority of selfinjections, thereby offering quality-of-life benefits [32]. Guidelines published by the Endocrine Society in 2018 recommended CSII use over MDI in populations with T1D who are capable of using the device and are not achieving glycemic control targets; are achieving targets but continuing to experience severe hypoglycemia or high glycemic variability; require increased flexibility with insulin administration or seek improved treatment satisfaction [30]. The Endocrine Society also recommended that, prior to CSII use, a structured evaluation should be performed assessing the individual's psychological status, historical adherence patterns, willingness to use and interest in the device, and availability for follow-up consultations [30]. All adults using CSII were also indicated to receive sufficient education, training, and ongoing support to achieve and maintain glycemic targets [30]. A position statement from the American Diabetes Association (ADA) indicated that viable candidates for CSII must be strongly motivated to improve glycemic control, and be willing to work in tandem with their healthcare professional to achieve treatment targets [33]. In addition, individuals must be appropriately trained to use the pump, perform SMBG testing, and interpret the measured data. Similar to the position statement for CGM, use of CSII was recommended alongside thorough education of PwD by skilled professionals [33]. However, the ADA acknowledged that physicians' opinions can vary when prescribing CSII, with some recommending pump therapy for motivated PwD with daily schedules unsuited to MDI, and others only endorsing prescription when treatment with MDI fails to achieve glycemic control [33]. A further consensus statement published in 2021 by the American Association of Clinical Endocrinologists/American College of Endocrinology (AACE/ACE) indicated that CSII should only be provided if the prescribing practice can offer a comprehensive pump management program for PwD [34]. Moreover, the AACE/ACE emphasized appropriate patient selection with a thorough assessment of the individual's knowledge of diabetes management principles [34]. Combination of these guidelines and position statements indicate the ideal CSII candidate as an individual with T1D currently performing four or more insulin injections and SMBG tests per day, who is motivated to achieve optimal glycemic control, and is willing and able to carry out the tasks associated with CSII safely and effectively, while maintaining frequent contact with their healthcare team [30, 34, 35].

\section{Sensor-Augmented and Sensor-Integrated Pumps}

Sensor-augmented pumps (SAPs) and sensorintegrated pumps (SIPs) combine CGM with CSII to form highly efficacious therapies. SAPs and SIPs differ in their response to CGM data: SAPs display CGM data and require the user to manually program their insulin pump, while SIPs integrate low-glucose suspend (LGS) or predictive LGS functions to automatically take action in response to CGM data (e.g., when blood glucose levels drop below or are predicted to drop below set targets) [36]. Published evidence has indicated that SAPs are associated with reduced moderate and severe hypoglycemia compared with MDI and reduced severe hypoglycemia compared with CSII, as well as improved blood glucose levels and glycemic variability versus sensor-augmented MDI therapy, while SIPs have been associated with a significantly reduced time spent in hypoglycemia and substantially fewer non-severe and severe hypoglycemic events compared with CSII in individuals with T1D with a high risk of hypoglycemia [37-39]. SIPs have also been associated with effective prevention of exerciseinduced hypoglycemia $[40,41]$.

\section{Hybrid Closed-Loop Systems}

Novel hybrid closed-loop (HCL) systems represent advanced diabetes technology that provide 
automated insulin delivery driven by algorithms, which can respond automatically to changes in blood glucose levels and administer basal and correction bolus insulin doses appropriately. Users must provide regular meal announcements and the corresponding carbohydrate intake to the device, but otherwise HCL systems have the potential to improve blood glucose control and reduce the risk of hypoglycemia compared with MDI, CSII, or non-automated SAP therapy. Moreover, HCL systems can decrease the self-management burden of T1D compared with other treatment modalities.

Predictive low-glucose management (PLGM) functions, a precursor to HCL systems, were associated with reduced diurnal and nocturnal hypoglycemia and significantly fewer hypoglycemic events in children and adolescents in a long-term randomized controlled trial published in 2018, as well as significantly improved TIR in a 2018 randomized crossover study, with participants noting that using the automated system was associated with less time thinking about diabetes, decreased worry about blood glucose levels, and decreased burden in managing diabetes $[42,43]$. HCL systems have been associated with significantly fewer hypoglycemic events and improved TIR compared with typical pump therapy with or without LGS [44-46]. HbA1c levels in both adolescents and adults have also been shown to significantly improve after 3 months on a first-generation HCL system, with significantly improved TIR compared with the device's manual mode [47]. Data from a 2019 randomized controlled trial indicated that TIR with HCL was higher versus the manual SAP mode after 6 months $(61 \%$ at baseline to $71 \%$ with HCL, versus unchanged at $59 \%$ in the manual SAP group [mean adjusted difference 11 percentage points; $95 \%$ confidence interval 9-14]; $p<0.001$ ) [48]. Furthermore, preliminary data from a pivotal trial of an advanced HCL system in the USA have indicated no severe hypoglycemia or diabetic ketoacidosis with the novel device, as well as improved HbA1c levels (72\% of individuals reaching an $\mathrm{HbA} 1 \mathrm{c}$ of $7.0 \%$ [53 $\mathrm{mmol} / \mathrm{mol}]$ after 90 days, compared with $52 \%$ at baseline, increasing to $84 \%$ with optimal system settings) and TIR $(69 \%$ of individuals reaching a TIR target of $70 \%$, compared with $45 \%$ at baseline, increasing to $79 \%$ with optimal system settings) [49]. The rate of users reported to utilize the closed-loop functionality of the device was 95\% [49]. Improved glycemic control, general wellbeing and sleep, as well as a reduced burden of diabetes and visible real-time glucose data have been identified as positive key elements in a recent study evaluating closed-loop versus SAP technology [50].

\section{Diabetes Technology Use in Central and Eastern Europe}

HCL systems represent the most advanced and the most effective form of insulin delivery currently available for people with T1D. However, novel diabetes technologies are often underutilized, particularly in Central and Eastern Europe (Figs. 1 and 2). The estimated uptake of insulin pump technology in T1D was $6.9 \%$ in Eastern Europe in 2018, and is not homogeneous across countries despite similar levels of healthcare expenditure (data on file). CGM uptake is also hindered by its high cost, as well as issues that remain even in modern systems: the need for regular sensor replacement as well as initial and regularly performed calibrations through SMBG testing [51].

A recent study reported the highest global rate of unconfirmed symptomatic hypoglycemia in people with T1D in Central and Eastern Europe, indicative of the underutilization of more advanced treatment options for T1D in this region [52]. Accordingly, large registry studies have demonstrated that low use of technology is associated with inadequate glycemic control and higher HbA1c levels [53, 54]. Wider use of diabetes technologies, including HCL systems, would provide clear glycemic control benefits for people with T1D, while decreasing the self-management burden with automated insulin delivery. However, current reimbursement criteria are not homogenous across Central and Eastern European countries, and numerous barriers to access exist for diabetes technology in the region that must be addressed to achieve more consistent and equal technology uptake. 


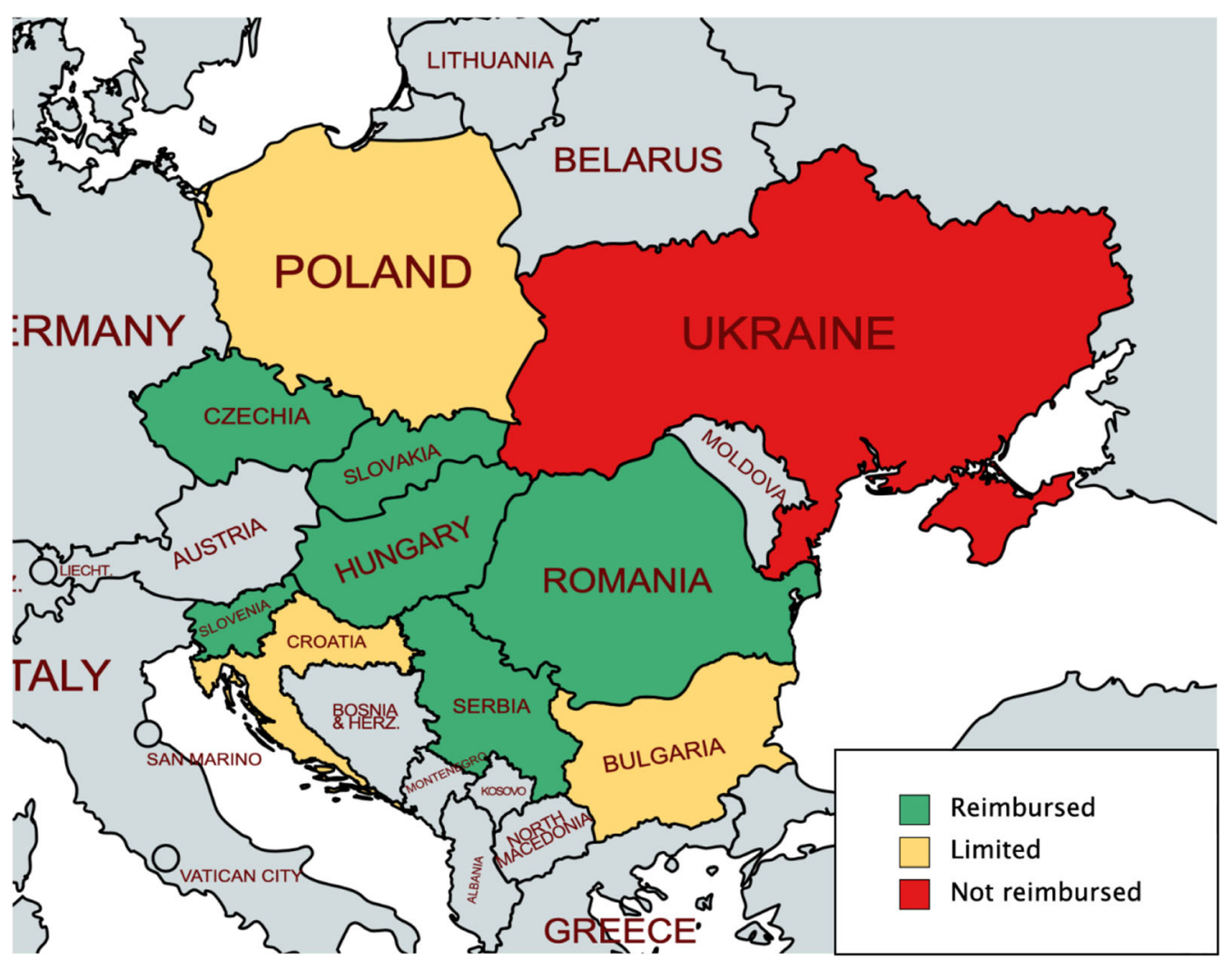

Fig. 1 Levels of reimbursement for CSII in Central and Eastern Europe

\section{CURRENT REIMBURSEMENT IN CENTRAL AND EASTERN EUROPE}

Guidelines for the reimbursement of CSII and SAP therapies in ten Central and Eastern European countries (Bulgaria, Croatia, Czechia, Hungary, Poland, Romania, Serbia, Slovakia, Slovenia, and Ukraine) were evaluated, based on country-specific national health insurance fund data [55-66].

\section{CSII Reimbursement}

Reimbursement of CSII was reported in Czechia, Romania, Serbia, Slovakia, and Slovenia, while limited reimbursement (supplemented with copay) was reported in Bulgaria and Poland (Fig. 1 and Table 2). In Croatia, reimbursement was covered by a national tender but with limited quantities of devices-individuals can otherwise cover the complete cost out-of-pocket. In
Hungary, reimbursement was reported only in individuals aged less than 18 years and only in special cases in individuals aged between 18 and 21 years, with a co-pay of $20 \%$ required in most cases for individuals aged 18 years or more. Ukraine was found to have no current reimbursement criteria for medical devices, with potential health technology assessment (HTA) guidelines under discussion.

Population criteria for reimbursement were similar across countries, encompassing both children and adults with T1D experiencing inadequate glycemic control and/or hypoglycemia. Poland restricts reimbursement to individuals with T1D aged at most 26 years and Ukraine limits prescription on a case-by-case basis in pediatric populations, but Bulgaria, Croatia, Czechia, Hungary, Romania, Serbia, Slovakia, and Slovenia have no age limits for reimbursement. Interestingly, despite similar population indications across the countries, 


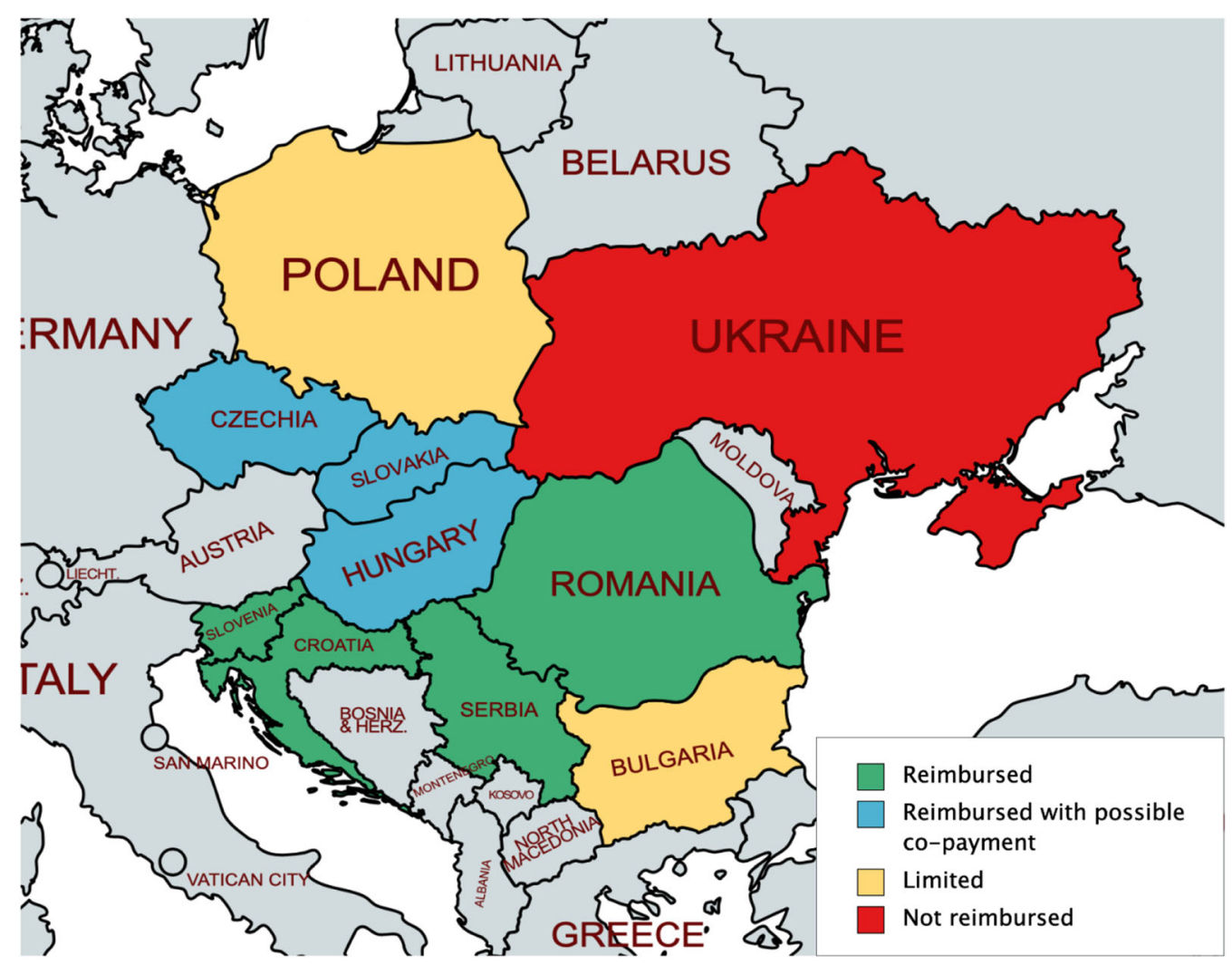

Fig. 2 Levels of reimbursement for SAP in Central and Eastern Europe

varying levels of estimated insulin pump uptake are reported in the Central and Eastern European region (data on file).

\section{SAP Reimbursement}

Reimbursement of SAP (CSII plus CGM) was reported in Croatia, Serbia, Romania, and Slovenia, with limited reimbursement (supplemented with co-pay) reported in Bulgaria, Hungary, Poland, and Slovakia (Fig. 2 and Table 3). Czechia was found to provide reimbursement of the insulin pump, but had an annual limited budget (supplemented with copay) for the sensor technology; novel HCL systems could therefore be reimbursed in Czechia under the current guidelines, should the price of the device fall within the annual budget. No specific reimbursement recommendations were found for Ukraine, with an HTA framework for medical devices under discussion.
Population indications for countries endorsing reimbursement varied. In Croatia, up to 40 sensors (plus one transmitter) per year are reimbursed for the SAP system in all individuals with T1D with existing insulin pumps and HbA1c levels greater than $7.5 \%(58 \mathrm{mmol} / \mathrm{mol})$. In Serbia, SAP reimbursement is limited to one of the following: PwD on MDI with three consecutive HbA1c measurements greater than $8.5 \%(69 \mathrm{mmol} / \mathrm{mol})$ in routine appointments; PwD on MDI with diabetic kidney disease with two consecutive HbA1c measurements greater than $7.5 \%(58 \mathrm{mmol} / \mathrm{mol})$; or pregnant individuals with two consecutive HbA1c measurements greater than $7.0 \% \quad(53 \mathrm{mmol} / \mathrm{mol})$. However, individuals with T1D receiving CSII therapy are eligible for up to 52 sensors and one transmitter per year in Serbia, irrespective of other criteria. In Slovenia, there are no restrictions on SAP reimbursement, with the primary indication being HbA1c and TIR targets, along with persistent hypoglycemia [31]. In countries 
Table 2 Reimbursement criteria for CSII in Central and Eastern Europe

\begin{tabular}{|c|c|c|c|c|}
\hline Country & $\begin{array}{l}\text { Reimbursement } \\
\text { status }\end{array}$ & $\begin{array}{l}\text { Healthcare } \\
\text { funding } \\
\text { type }\end{array}$ & Population indications & Economic details \\
\hline $\begin{array}{c}\text { Bulgaria } \\
\text { [55] }\end{array}$ & Limited & $\begin{array}{l}\text { National } \\
\text { insurance }\end{array}$ & $\begin{array}{l}\text { Confirmed diagnosis of T1D } \\
\text { Unsuccessful intensified therapy } \\
\text { with insulin analogues with at } \\
\text { least four applications per day } \\
\text { Frequent and unpredictable severe } \\
\text { daytime and/or nocturnal } \\
\text { hypoglycemia } \\
\text { High blood sugar in the morning } \\
\text { (dawn phenomenon) } \\
\text { Inadequate glycemic control- } \\
\text { HbA1c }>8.5 \% \text { ( } 69 \mathrm{mmol} / \mathrm{mol} \text { ) } \\
\text { (< } 18 \text { years of age } \mathrm{HbA} 1 \mathrm{c} \\
\text { over }>7.5 \% \text { [ } 58 \mathrm{mmol} / \mathrm{mol}]) \\
\text { Children }<6 \text { years of age } \\
\text { Pregnancy or planned pregnancy } \\
\text { and a persistently high level of } \\
\text { HbAlc }>7.0 \% \text { ( } 53 \mathrm{mmol} / \mathrm{mol} \text { ) }\end{array}$ & $\begin{array}{l}\text { Insulin pumps provided by } \\
\text { manufacturers, and NHIF pays } \\
\text { fixed amount per product for } \\
\text { intensified insulin treatment: } \\
\text { Up to } 10 \text { pieces per month of } \\
\text { infusion sets and reservoirs } \\
\text { according to medical criteria and } \\
\text { instructions } \\
\text { Co-pay covers remaining amount }\end{array}$ \\
\hline $\begin{array}{c}\text { Croatia } \\
{[56]}\end{array}$ & Limited & $\begin{array}{l}\text { National } \\
\text { insurance }\end{array}$ & $\begin{array}{l}\text { People with T1D with uncontrolled } \\
\text { HbA1c, glycemic variability, } \\
\text { frequent hypoglycemia, dawn } \\
\text { phenomenon, unregulated } \\
\text { glycemia, preconception }\end{array}$ & $\begin{array}{l}\text { Insulin pumps funded through } \\
\text { national tender in about } 95 \% \text { of } \\
\text { cases } \\
\text { Consumables are } 100 \% \text { reimbursed } \\
\text { for all people with a pump } \\
\text { No co-pay for any devices, but PwD } \\
\text { can cover the full cost of the } \\
\text { device out-of-pocket if not } \\
\text { covered through national tender }\end{array}$ \\
\hline
\end{tabular}


Table 2 continued

\begin{tabular}{|c|c|c|c|c|}
\hline Country & $\begin{array}{l}\text { Reimbursement } \\
\text { status }\end{array}$ & $\begin{array}{l}\text { Healthcare } \\
\text { funding } \\
\text { type }\end{array}$ & Population indications & Economic details \\
\hline $\begin{array}{l}\text { Czech } \\
\text { Republik } \\
{[57]}\end{array}$ & Reimbursed & $\begin{array}{l}\text { National } \\
\text { insurance }\end{array}$ & $\begin{array}{l}\text { Both children and adults } \\
\text { Recurrent and unrecognized } \\
\text { hypoglycemia that cannot be } \\
\text { controlled by other therapeutic } \\
\text { methods (including analogue- } \\
\text { Lantus administration) } \\
\text { Significant dawn phenomenon } \\
\text { Preconception stage and pregnancy, } \\
\text { if successful treatment of diabetes } \\
\text { by another intensified regimen is } \\
\text { not achieved } \\
\text { Prevention of or beneficial influence } \\
\text { on diabetes-related microvascular } \\
\text { complications with long-term } \\
\text { inadequate glycemic control on } \\
\text { other insulin regimens, plus } \\
\text { evidence of improvements during } \\
\text { pump therapy } \\
\text { Protection of a transplanted kidney } \\
\text { in PwD who have had their graft } \\
\text { rejected or who have not had a } \\
\text { pancreatic transplant } \\
\text { Must be prescribed by a physician } \\
\text { specialized in diabetology } \\
\text { (Centralized Diabetology Clinics) } \\
\text { and approved by health insurance } \\
\text { Reimbursement is limited to one } \\
\text { pump per treating physician every } \\
4 \text { years }\end{array}$ & $\begin{array}{l}\text { 100\% reimbursed, with a price cap } \\
\text { (regulation of State Institute on } \\
\text { Drug Control) } \\
\text { There are three reimbursement } \\
\text { categories } \\
\text { Basic pump (CSII) } \\
\text { CGM only } \\
\text { SAP }\end{array}$ \\
\hline
\end{tabular}


Table 2 continued

\begin{tabular}{|c|c|c|c|c|}
\hline Country & $\begin{array}{l}\text { Reimbursement } \\
\text { status }\end{array}$ & $\begin{array}{l}\text { Healthcare } \\
\text { funding } \\
\text { type }\end{array}$ & Population indications & Economic details \\
\hline $\begin{array}{c}\text { Hungary } \\
{[58]}\end{array}$ & Reimbursed & $\begin{array}{l}\text { National } \\
\text { insurance }\end{array}$ & $\begin{array}{l}\text { People with uncontrolled T1D in } \\
\text { one of the following areas: } \\
\text { Repeated HbAlc }>7.0 \% \\
\text { ( } 53 \mathrm{mmol} / \mathrm{mol} \text { ), pre-conceptual } \\
\text { care }>6.5 \% \text { ( } 48 \mathrm{mmol} / \mathrm{mol}) \\
\text { Significant daily blood glucose } \\
\text { fluctuations ( } \geq 10.0 \mathrm{mmol} / \mathrm{L} \text { ) } \\
\text { Early morning fast (morning } \\
\text { fasting blood glucose) } \\
\text { repeatedly }>8.0 \mathrm{mmol} / \mathrm{L} \\
\text { Hypoglycemia with clinical } \\
\text { symptoms at least } 3 \text { times per } \\
\text { month } \\
\text { Documented reduction or loss of } \\
\text { hypoglycemia } \\
\text { Severe hypoglycemia (blood } \\
\text { glucose }<3.0 \text { mmol/L) at least } \\
\text { once every } 6 \text { months } \\
\text { People with T1D with recurrent } \\
\text { (> } 3 \text { times per year) or severe } \\
\text { (requiring hospital admission) } \\
\text { ketoacidosis } \\
\text { One of the following must be } \\
\text { satisfied for treatment } \\
\text { continuation: } \\
\text { Mean HbAlc value }<8.0 \% \\
\text { (64 mmol/mol) during previous } \\
6 \text { months, plus HbAlc value } \\
\text { (before daily blood glucose } \\
\text { fluctuations) less than before } \\
\text { pump therapy } \\
\text { Reduced number of symptomatic } \\
\text { or asymptomatic hypoglycemic } \\
\text { events compared with period } \\
\text { before pump therapy }\end{array}$ & $\begin{array}{l}\text { Prior authorization required, } \\
\text { involving substantial paperwork } \\
\text { Co-payment system: } \\
\text { Aged }<18 \text { years: } 98 \% \text { reimbursed } \\
\text { plus } 2 \% \text { co-payment } \\
\text { Aged }>18 \text { years with cystic } \\
\text { fibrosis: } 80 \% \text { reimbursed plus } 20 \% \\
\text { co-payment } \\
3 \text { months' probation time (products } \\
\text { provided free of charge by } \\
\text { distributor) - upgrade on pumps } \\
\text { only under strict conditions } \\
\text { NHIF has a yearly budget for } \\
\text { pumps, managed through } \\
\text { price-volume agreements }\end{array}$ \\
\hline
\end{tabular}


Table 2 continued

\begin{tabular}{|c|c|c|c|c|}
\hline Country & $\begin{array}{l}\text { Reimbursement } \\
\text { status }\end{array}$ & $\begin{array}{l}\text { Healthcare } \\
\text { funding } \\
\text { type }\end{array}$ & Population indications & Economic details \\
\hline $\begin{array}{l}\text { Poland } \\
\qquad[59,60]\end{array}$ & Limited & $\begin{array}{l}\text { National } \\
\text { insurance }\end{array}$ & $\begin{array}{l}\text { People with T1D aged }<26 \text { years } \\
\text { diagnosed with one or more of } \\
\text { the following: } \\
\text { Repetitive severe hypoglycemia } \\
\text { Repetitive hypoglycemia at dawn } \\
\text { Glucose instability requiring } \geq 7 \\
\text { measurements per day } \\
\text { Presence of diabetes-related } \\
\text { complications/ketoacidosis }\end{array}$ & $\begin{array}{l}\text { Insulin pumps reimbursed through } \\
\text { the DRG system; tariffs set by } \\
\text { AOTMIT (HTA body) with no } \\
\text { co-pay allowed } \\
\text { Public funding limits apply for } \\
\text { pump consumables (i.e., fixed } \\
\text { amounts for reservoirs [up to } \\
5 \text { units per month]; infusion sets } \\
\text { [up to } 10 \text { units per month]) }\end{array}$ \\
\hline $\begin{array}{c}\text { Romania } \\
{[61]}\end{array}$ & Reimbursed & Tender & $\begin{array}{l}\text { People with T1D or T2D, } \\
\text { prioritized as follows: } \\
\text { Children aged }<18 \text { years } \\
\text { Between } 18 \text { and } 26 \text { years of age } \\
\text { with no income } \\
\text { Pregnant individuals } \\
\text { Adults }\end{array}$ & $\begin{array}{l}\text { 100\% reimbursement, no co-pay } \\
\text { Tender market for all diabetes- } \\
\text { related devices } \\
\text { Therapy bundles (CSII/CGM/ } \\
\text { SAP) are available, set by the payer } \\
\text { and MoH with input from the } \\
\text { DIB Health Committee }\end{array}$ \\
\hline $\begin{array}{l}\text { Serbia } \\
\qquad[62-64]\end{array}$ & Reimbursed & $\begin{array}{l}\text { National } \\
\text { insurance }\end{array}$ & $\begin{array}{l}\text { People with T1D administering } \\
\text { MDI with inadequate glycemic } \\
\text { control } \\
\text { Adults with an HbAlc } \geq 8.5 \% \\
\text { (69 } \mathrm{mmol} / \mathrm{mol} \text { ) or } \\
\mathrm{HbAlc} \geq 7.5 \% \text { ( } 58 \mathrm{mmol} / \mathrm{mol}) \\
\text { plus microalbuminuria } \\
\text { Children with an HbAlc } \geq 7.5 \% \\
\text { (58 mmol/mol) or brittle diabetes } \\
\text { Pregnant individuals with an } \\
\text { HbAlc } \geq 7.0 \% \text { ( } 53 \mathrm{mmol} / \mathrm{mol})\end{array}$ & $\begin{array}{l}\text { Pump, infusion sets, and reservoirs } \\
(120 \text { per year }) \text { are fully } \\
\text { reimbursed according to defined } \\
\text { clinical indications }\end{array}$ \\
\hline
\end{tabular}


Table 2 continued

\begin{tabular}{|c|c|c|c|c|}
\hline Country & $\begin{array}{l}\text { Reimbursement } \\
\text { status }\end{array}$ & $\begin{array}{l}\text { Healthcare } \\
\text { funding } \\
\text { type }\end{array}$ & Population indications & Economic details \\
\hline $\begin{array}{c}\text { Slovakia } \\
\text { [65] }\end{array}$ & Reimbursed & $\begin{array}{l}\text { National } \\
\text { insurance }\end{array}$ & $\begin{array}{l}\text { All people with diabetes: } \\
\text { Individuals on intensified insulin } \\
\text { treatment with } \mathrm{HbAlc}>8.0 \% \\
\text { (64 mmol/mol) and/or significant } \\
\text { hypoglycemia and/or significant } \\
\text { glucose variability despite the use } \\
\text { of a long-acting insulin analogue } \\
\text { (minimum } 6 \text { months) } \\
\text { Inadequate glycemic control before } \\
\text { a planned pregnancy/during } \\
\text { pregnancy } \\
\text { Individuals at increased mortality } \\
\text { risk (i.e., with CVD } \\
\text { complications), with premature } \\
\text { occurrence/rapid progression of } \\
\text { complications, or post organ } \\
\text { transplantation } \\
\text { Continuation criteria: } \\
\text { Minimum } 6 \text { months of monitoring } \\
\text { in diabetology center } \\
\text { Confirmed improvement in } \\
\text { glycemic control (compared to the } \\
\text { initial indication) }\end{array}$ & $\begin{array}{l}\text { Pump (one per } 4 \text { years), infusion } \\
\text { sets (120 per year) and reservoirs } \\
(100 \text { per year) are fully } \\
\text { reimbursed with no co-pay }\end{array}$ \\
\hline $\begin{array}{c}\text { Slovenia } \\
{[66]}\end{array}$ & Reimbursed & $\begin{array}{l}\text { National } \\
\text { insurance }\end{array}$ & $\begin{array}{l}\text { People with T1D with: } \\
\text { Unmet glycemic targets despite } \\
\text { treatment with MDI } \\
\text { Hypoglycemia unawareness } \\
\text { High glycemic variability when } \\
\text { receiving MDI (in } \\
\text { ages }<18 \text { years) } \\
\text { Diagnosis when aged }<7 \text { years } \\
\text { Pregnancy or planned pregnancy } \\
\text { and unmet glycemic targets } \\
\text { despite treatment with MDI }\end{array}$ & $\begin{array}{l}\text { CSII components (pump and } \\
\text { consumables) are reimbursed } \\
\text { through the generic } \\
\text { reimbursement amounts defined } \\
\text { by the payer body, the ZZZS }\end{array}$ \\
\hline
\end{tabular}


Table 2 continued

\begin{tabular}{lllll}
\hline Country & $\begin{array}{l}\text { Reimbursement } \\
\text { status }\end{array}$ & $\begin{array}{l}\text { Healthcare } \\
\text { funding } \\
\text { type }\end{array}$ & Population indications & Economic details \\
\hline Ukraine & Not reimbursed & $\begin{array}{l}\text { Occasional } \\
\text { tender }\end{array}$ & $\begin{array}{c}\text { Case-by-case basis in pediatric } \\
\text { individuals }\end{array}$ & $\begin{array}{c}\text { Occasional, limited, regional } \\
\text { funding for consumables for } \\
\text { pediatric individuals through } \\
\text { tenders }\end{array}$ \\
\hline
\end{tabular}

CGM continuous glucose monitoring, CSII continuous subcutaneous insulin infusion, $C V D$ cardiovascular disease, HbAIc glycated hemoglobin, $M D I$ multiple daily insulin, $M o H$ Ministry of Health, NHIF National Health Insurance Fund, $P w D$ people with diabetes, SAP sensor-augmented pump, TID type 1 diabetes, T2D type 2 diabetes, ZZZS Zavod za zdravstveno zavarovanje Slovenije [Health Insurance Institute of Slovenia]

with partial reimbursement, population indications were comparable, with fixed reimbursable amounts set by national healthcare authorities and co-pay above these thresholds.

The lack of uptake and indifference to novel diabetes technologies are evidenced by these reimbursement criteria, with CSII reimbursed in six countries, but SAP reimbursed in only four countries. The panel aimed to assess the potential barriers to reimbursement and use of diabetes technologies, and provide solutions to potentially avoid similar lack of uptake of novel HCL systems, given the clinical benefits that these devices offer [42, 43, 47-49].

\section{BARRIERS TO TECHNOLOGY USE IN TYPE 1 DIABETES}

The panel discussed several key barriers to technology use in the Central and Eastern European region, which can be broken down into several categories (Table 4).

\section{Access and Funding}

A key issue in Central and Eastern European countries is the lack of funding for novel medical devices, with available public resources more limited compared with Western European countries $[67,68]$. This is particularly pertinent for treatments for T1D-funding may not be present for novel technologies when the more affordable MDI therapy is the alternative, and when short-term financial drivers override longterm health economic benefits. While lack of funding represents the major problem in the region, nascent HTA agencies are also a hindrance in some Central and Eastern European countries, such as Romania and Ukraine-these agencies have less health economic expertise to draw from than their Western European counterparts, which have long-running and experienced HTA bodies in place [such as the National Institute for Health and Care Excellence (NICE) in England, the Haute Autorite de santé (HAS) in France, and the Institut für Qualität und Wirtschaftlichkeit im Gesundheitswesen (IQWiG) in Germany] [69-72]. Outdated and non-evidence-based eligibility criteria for novel therapies can prevent PwD receiving new, efficacious technologies, particularly if funding is instead diverted to medications at high prices with limited health gains [73-76]. It has been suggested that HTA implementation in the Central and Eastern European region be particularly resource-conscious, with transferability of evidence (e.g., clinical evidence, HTA methodology, and policy) between countries in the region emphasized wherever possible [77]. However, the aspects of HTA that are transferable between countries should be carefully considered, given that each country faces its own unique challenges and comprises different populations.

Lack of resources and funding also influences the level of education both physicians and PwD have access to, which can limit knowledge of 
Table 3 Reimbursement criteria for SAP in Central and Eastern Europe

\begin{tabular}{|c|c|c|c|c|}
\hline Country & $\begin{array}{l}\text { Reimbursement } \\
\text { status }\end{array}$ & $\begin{array}{l}\text { Healthcare } \\
\text { funding type }\end{array}$ & Population indications & Economic details \\
\hline $\begin{array}{c}\text { Bulgaria } \\
\text { [55] }\end{array}$ & Limited & $\begin{array}{l}\text { National } \\
\text { insurance for } \\
\text { pump, out-of- } \\
\text { pocket for } \\
\text { CGM }\end{array}$ & $\begin{array}{l}\text { Confirmed diagnosis of T1D } \\
\text { Unsuccessful intensified therapy with insulin } \\
\text { analogues with at least four applications per } \\
\text { day } \\
\text { Frequent and unpredictable severe daytime and/ } \\
\text { or nocturnal hypoglycemia } \\
\text { High blood sugar in the morning (dawn } \\
\text { phenomenon) } \\
\text { Inadequate glycemic control-HbAlc }>8.5 \% \\
(69 \mathrm{mmol} / \mathrm{mol})(<18 \text { years of age } \mathrm{HbAlc} \\
\text { over }>7.5 \% \text { [ } 58 \mathrm{mmol} / \mathrm{mol}]) \\
\text { Children }<6 \text { years of age } \\
\text { Pregnancy or planned pregnancy and a } \\
\text { persistently high level of } \mathrm{HbAlc}>7.0 \% \\
\text { ( } 53 \mathrm{mmol} / \mathrm{mol} \text { ) }\end{array}$ & $\begin{array}{l}\text { NHIF pays fixed amount per product for } \\
\text { intensified insulin treatment, but no price set } \\
\text { for sensors/CGM and they are therefore fully } \\
\text { funded out-of-pocket }\end{array}$ \\
\hline Croatia [56] & Reimbursed & $\begin{array}{l}\text { National } \\
\quad \text { insurance }\end{array}$ & $\begin{array}{l}\text { CGM/SAP reimbursed for all individuals that } \\
\text { are insulin pump users with HbAlc } \\
\text { levels }>7.5 \%(58 \mathrm{mmol} / \mathrm{mol})\end{array}$ & $\begin{array}{l}\text { Product-based reimbursement prices (for pump, } \\
\text { consumables, and CGM sensors) are set by } \\
\text { the payer body, the HZZO } \\
\text { Up to } 40 \text { sensors per year (plus one transmitter) } \\
\text { are covered }\end{array}$ \\
\hline $\begin{array}{l}\text { Czech } \\
\text { Republik } \\
\text { [57] }\end{array}$ & $\begin{array}{l}\text { Reimbursed with } \\
\text { possible co- } \\
\text { payment }\end{array}$ & $\begin{array}{l}\text { National } \\
\text { insurance }\end{array}$ & $\begin{array}{l}\text { CGM/SAP is covered for T1D for any age on } \\
\text { CSII (or MDI) if individual with T1D meets } \\
\text { CGM/SAP/CSII reimbursement criteria } \\
\text { Recurrent and unrecognized hypoglycemia that } \\
\text { cannot be controlled by other therapeutic } \\
\text { methods (including analogue-Lantus } \\
\text { administration) } \\
\text { Significant dawn phenomenon } \\
\text { Preconception stage and pregnancy, if successful } \\
\text { treatment of diabetes by another intensified } \\
\text { regimen is not achieved } \\
\text { Prevention of or beneficial influence on } \\
\text { diabetes-related microvascular complications } \\
\text { with long-term inadequate glycemic control } \\
\text { on other insulin regimens, plus evidence of } \\
\text { improvements during pump therapy } \\
\text { Protection of a transplanted kidney in } \\
\text { individuals who have had their graft rejected } \\
\text { or who have not had a pancreatic transplant } \\
\text { Must be prescribed by a physician specialized in } \\
\text { diabetology (Centralized Diabetology Clinics) } \\
\text { and approved by health insurance } \\
\text { Reimbursement is limited to one pump per } \\
\text { treating physician every } 4 \text { years }\end{array}$ & $\begin{array}{l}\text { Reimbursement limit applies for the CGM per } \\
\text { person per year; co-payment in cases where } \\
\text { person exceeds the reimbursement limit }\end{array}$ \\
\hline
\end{tabular}


Table 3 continued

\begin{tabular}{|c|c|c|c|c|}
\hline Country & $\begin{array}{l}\text { Reimbursement } \\
\text { status }\end{array}$ & $\begin{array}{l}\text { Healthcare } \\
\text { funding type }\end{array}$ & Population indications & Economic details \\
\hline $\begin{array}{c}\text { Hungary } \\
{[58]}\end{array}$ & $\begin{array}{l}\text { Reimbursed with } \\
\text { possible co- } \\
\text { payment }\end{array}$ & $\begin{array}{l}\text { National } \\
\text { insurance }\end{array}$ & $\begin{array}{l}\text { Aged }<18 \text { years, with T1D and cystic fibrosis } \\
\text { Aged }>18 \text { years, with T1D and cystic fibrosis } \\
\text { with: } \\
\text { Hypoglycemia unawareness } \\
\text { Frequent hypoglycemia (five events per month) } \\
\text { Severe hypoglycemia (BG }<3.0 \mathrm{mmol} / \mathrm{L} \text { ) } \\
\text { HbA1c }>8.0 \%(64 \mathrm{mmol} / \mathrm{mol}) \\
\text { Pregnancy or planned pregnancy (within next } \\
6 \text { months) } \\
\text { CGM-naïve individuals start with a } 4 \text {-week } \\
\text { "probation time", after which } \\
\text { individuals/physicians decide whether to start } \\
\text { official CGM therapy with prescription } \\
\text { Evaluation every } 6 \text { months (physician can } \\
\text { prescribe } 24 \text { sensors for } 6 \text { months) - criteria } \\
\text { to continue the CGM are sensor usage at least } \\
70 \% \text { of time plus one of: } \\
\text { Fewer hypoglycemic events than before CGM } \\
\text { Increased time in range } \\
\text { Hb1Ac in individual target range }\end{array}$ & $\begin{array}{l}\text { Co-payment system: } \\
\text { Aged }<18 \text { years: } 98 \% \text { reimbursed }+2 \% \text { co- } \\
\text { payment } \\
\text { For individuals with T1D with cystic fibrosis } \\
\text { Aged }>18 \text { years: } 80 \% \text { reimbursed }+20 \% \text { co- } \\
\text { payment } \\
\text { For individuals with T1D with cystic fibrosis } \\
\text { and any complication (as shown in the } \\
\text { "Population indications" column): } \\
4 \text { weeks' probation time (products provided } \\
\text { free of charge by distributor) } \\
\text { Sensor quantity: } 12 \text { units per } 3 \text { months per } \\
\text { prescription ( } 48 \text { units per year) } \\
\text { 2-year warranty for transmitters }\end{array}$ \\
\hline $\begin{array}{l}\text { Poland } \\
\qquad[59,60]\end{array}$ & Limited & $\begin{array}{l}\text { National } \\
\text { insurance }\end{array}$ & $\begin{array}{l}\text { T1D insulin pump users with hypoglycemia } \\
\text { unawareness, for individuals aged } \leq 26 \text { years }\end{array}$ & $\begin{array}{l}\text { Reimbursement limits set by the Polish payer } \\
\text { body applies: } \\
\text { Four sensors per month with reimbursement } \\
\text { limit and } 30 \% \text { co-payment } \\
\text { One transmitter per } 8 \text { months with } \\
\text { reimbursement limit and 30\% co-payment }\end{array}$ \\
\hline $\begin{array}{c}\text { Romania } \\
{[61]}\end{array}$ & Reimbursed & Tender & $\begin{array}{l}\text { T1D children on a CGM with a coefficient of } \\
\text { variability }>36 \% \\
\text { T1D adults on a CGM with at least two } \\
\text { hypoglycemic comas in the last } 6 \text { months } \\
\text { (proven through hospitalization) } \\
\text { Individuals that are already on a pump without } \\
\text { sensors are eligible for SAP only if their } \\
\text { current pump is out of warranty }\end{array}$ & $\begin{array}{l}100 \% \text { reimbursement, no co-pay } \\
\text { Tender market for all diabetes-related devices } \\
\text { Therapy bundles (CSII/CGM/SAP) are } \\
\text { available, set by the payer and MoH with } \\
\text { input from the DIB Health Committee }\end{array}$ \\
\hline $\begin{array}{l}\text { Serbia } \\
\quad[62-64]\end{array}$ & Reimbursed & $\begin{array}{l}\text { National } \\
\text { insurance }\end{array}$ & $\begin{array}{l}\text { Individuals on MDI with three consecutive } \\
\mathrm{HbAlc} \text { measurements }>8.5 \% \\
(69 \mathrm{mmol} / \mathrm{mol}) \text { in routine appointments } \\
\text { Individuals on MDI with diabetic kidney } \\
\text { disease with two consecutive } \mathrm{HbAlc} \\
\text { measurements }>7.5 \%(58 \mathrm{mmol} / \mathrm{mol}) \\
\text { Pregnant individuals with two consecutive } \\
\text { HbAlc measurements }>7.0 \% \\
\text { ( } 53 \mathrm{mmol} / \mathrm{mol}) \\
\text { Individuals with T1D receiving CSII }\end{array}$ & $\begin{array}{l}\text { Product-specific reimbursement amounts and } \\
\text { quantities apply } \\
\text { Individuals receiving CSII are limited to } 52 \\
\text { sensors and one transmitter per year }\end{array}$ \\
\hline
\end{tabular}


Table 3 continued

\begin{tabular}{|c|c|c|c|c|}
\hline Country & $\begin{array}{l}\text { Reimbursement } \\
\text { status }\end{array}$ & $\begin{array}{l}\text { Healthcare } \\
\text { funding type }\end{array}$ & Population indications & Economic details \\
\hline $\begin{array}{c}\text { Slovakia } \\
{[65]}\end{array}$ & $\begin{array}{l}\text { Reimbursed with } \\
\text { possible co- } \\
\text { payment }\end{array}$ & $\begin{array}{l}\text { National } \\
\quad \text { insurance }\end{array}$ & $\begin{array}{l}\text { Pregnant women with T1D } \\
\text { Children with T1D (aged }<19 \text { years) } \\
\text { Adults with T1D receiving insulin pump } \\
\text { therapy with LGS or PLGM, with } \\
\text { hypoglycemia unawareness and high } \\
\text { cardiovascular risk } \\
\text { Continuation criteria: } \\
\text { Minimum } 6 \text { months of monitoring in a } \\
\text { diabetology center } \\
\text { Confirmed improvement in glycemic control } \\
\text { (compared to initial indication) }\end{array}$ & $\begin{array}{l}\text { Substantial reimbursement of sensors with little } \\
\text { co-pay } \\
\text { Pregnant women with T1D: } 40 \text { sensors } \\
\text { Children with T1D aged }<19 \text { years: } 70-80 \% \\
\text { time on sensors per year (up to } 42 \text { sensors per } \\
\text { year) } \\
\text { Adults with T1D aged } \geq 19 \text { years on SAP } \\
\text { therapy with LGS or PLGM, with } \\
\text { hypoglycemia unawareness and high } \\
\text { cardiovascular risk: } 26 \text { sensors per year } \\
\text { Transmitter } 100 \% \text { covered for individuals } \\
\text { fulfilling the following indications: } \\
\text { Pregnant women with T1D } \\
\text { Children with T1D aged }<18 \text { years on SAP } \\
\text { therapy with LGS or PLGM }\end{array}$ \\
\hline $\begin{array}{c}\text { Slovenia } \\
{[66]}\end{array}$ & Reimbursed & $\begin{array}{l}\text { National } \\
\quad \text { insurance }\end{array}$ & $\begin{array}{l}\text { Personal CGM reimbursement covers: } \\
\text { Pediatric individuals with T1D aged } \leq 7 \text { years } \\
\text { Pregnant women with T1D on intensive } \\
\text { insulin treatment } \\
\text { Intermittently scanned CGM is reimbursed for } \\
\text { all people with T1D with significant glycemic } \\
\text { variability despite treatment with MDI } \\
\text { CGM reimbursement is also covered in } \\
\text { individuals with T1D receiving CSII, MDI } \\
\text { plus SMBG or intermittently scanned CGM } \\
\text { with one of the following: } \\
\text { HbAlc values > 7.0\% ( } 53 \text { mmol/mol) } \\
\text { TIR (3.9-10.0\%) < 70\% across } 3 \text { months } \\
\text { Recurring severe hypoglycemia with } \\
\text { TBR > 4.0\% } \\
\text { HCL reimbursement is covered in individuals } \\
\text { with T1D receiving CSII, CSII plus CGM, or } \\
\text { MDI plus CGM with one of the following: } \\
\text { HbAlc values > 7.0\% ( } 53 \text { mmol/mol) } \\
\text { TIR (3.9-10.0\%) < 70\% across } 3 \text { months [31] } \\
\text { Recurring severe hypoglycemia with } \\
\text { TBR > 4.0\% } \\
\text { Reimbursement of all devices is contingent on } \\
\text { individuals actively participating in their } \\
\text { diabetes management and if the use of devices } \\
\text { is expected to improve their diabetes } \\
\text { management }\end{array}$ & $\begin{array}{l}\text { Generic reimbursement of } 52 \text { sensors plus one } \\
\text { transmitter per year }\end{array}$ \\
\hline Ukraine & Not reimbursed & - & 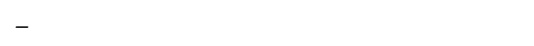 & - \\
\hline
\end{tabular}

CGM continuous glucose monitoring, CSII continuous subcutaneous insulin infusion, CVD cardiovascular disease, HbAIc glycated hemoglobin, $H Z Z O$ Hrvatski zavod za zdravstveno osiguranje [Croatian Health Insurance Fund], LGS low glucose suspend, MoH Ministry of Health, NHIF National Health Insurance Fund, $P L G M$ predictive low glucose management, $S A P$ sensor-augmented pump, $S M B G$ self-monitoring of blood glucose, $T I D$ type 1 diabetes, $T 2 D$ type 2 diabetes, TBR time below range, $T I R$ time in range 
diabetes technologies and hinder uptake. Fewer resources and less funding can lead to fewer diabetes-specific treatment clinics and less specialized care, particularly in rural areas [78, 79].

\section{Human Factors}

Human factors include perceptions, beliefs, attitudes, expectations, and preferences for treatment modalities for T1D. Lack of awareness of available therapies for both physicians and $\mathrm{PwD}$, stemming from insufficient education on diabetes technologies, can limit the treatment options that can be prescribed and lead to apathy in achieving treatment targets. Fear and experience of hypoglycemia, a common side effect of MDI therapy, can also limit adherence to treatments and cause therapeutic inertia and subsequent inadequate glycemic control [14-16]. Fear of these events continuing or worsening on novel technologies, the benefits of which can be largely unknown to PwD, could also drive lack of uptake. A high level of knowledge and education has been identified as a key factor behind treatment adherence and maintained glycemic control in numerous studies, and indifference in achieving treatment targets can lead to acceptance of inefficacious treatments, inadequate glycemic control, and an increased clinical and economic burden on healthcare systems [80].

Differences between adult and pediatric populations with T1D should also be noted. Countries such as Poland and Hungary have age limits on reimbursement criteria, and PwD can therefore lose access to technologies as they age. It is perhaps a misconception that older PwD may be less willing to adopt and learn how to use novel technologies; data have shown a willingness to do so, provided enough support is offered [81]. Indeed, some younger PwD have been associated with less use of diabetes technologies due to an aversion of wearing the devices [82].

\section{Healthcare System Capacity Limitations}

Tied to the lack of overall resources in the Central and Eastern European region, the physical capacity of clinics to deal with structured education of physicians and PwD is a potential issue. Moreover, the number of adequately trained and knowledgeable physicians who can effectively inform PwD of the available treatment options (and how to use technologies such as CSII and SAP) is suboptimal. In Czechia in 2018 , data on file indicated 581 care providers and a calculated estimate of 480 full-time diabetologists working in specialized diabetes departments, while in Slovakia, the total number of diabetologists was estimated to be 285 , meaning one diabetologist was caring for approximately $1200 \mathrm{PwD}$ [83]. The number of diabetologists in the region varies from country to country, but similar patterns emerge: an estimated 36 (13 for pediatric populations) specialized diabetology pump centers in Hungary; a total of 1929 endocrinologists for the diabetic population (and 185 pediatric endocrinologists for 10,743 children with diabetes) in Ukraine; approximately 1500 diabetologists in Romania; and 1300 specialists in Poland, where approximately 1500 are required for the population size [79]. In these cases, diabetes care must be provided by general practitioners, who may or may not be educated enough to provide informed decisions and technology training for PwD.

\section{Steps Towards Optimizing Technology Use in Type 1 Diabetes}

Advanced technologies can provide numerous clinical benefits for individuals with T1D, and yet their use remains limited, particularly in Central and Eastern Europe. On the basis of the barriers to uptake discussed in the present paper, the panel recommends application of basic, evidence-based, regional guidelines for the use of technology in the treatment of T1D that can be applied locally according to the specific requirements and abilities of each country. These should incorporate structured education of physicians and PwD to increase the knowledge of potential treatment options and improve skills in using advanced devices, thereby improving efficiency and driving uptake. 
Table 4 Potential barriers and solutions to diabetes technology use

\begin{tabular}{|c|c|}
\hline Barrier & Potential solutions \\
\hline \multicolumn{2}{|l|}{ Physical access and funding } \\
\hline Underdeveloped HTA bodies & $\begin{array}{l}\text { Development of regional and national HTA guidelines with } \\
\text { emphasis on transferability to maximize resources }\end{array}$ \\
\hline High initial outlay on diabetes technologies & $\begin{array}{l}\text { Further development of HTA bodies to allow health economic } \\
\text { modeling to reveal cost-effective therapies and drive decision- } \\
\text { making }\end{array}$ \\
\hline \multicolumn{2}{|l|}{ Human factors } \\
\hline Apathy towards treatment targets & $\begin{array}{l}\text { Improved presentation of therapies to emphasize potential benefits } \\
\text { of improved engagement and adherence }\end{array}$ \\
\hline $\begin{array}{l}\text { Younger individuals not as engaged with diabetes } \\
\text { technologies (wearable devices not fashionable) }\end{array}$ & $\begin{array}{l}\text { Improved physical features relating to the wearing of the devices to } \\
\text { make devices more appealing to young adults, as well as } \\
\text { emphasizing the benefits of the technology (improved glycemic } \\
\text { control, less hypoglycemia, reduced micromanaging of insulin } \\
\text { administrations) }\end{array}$ \\
\hline \multicolumn{2}{|l|}{ Healthcare system capacity limitations } \\
\hline $\begin{array}{l}\text { Not enough specialized, adequately trained } \\
\text { healthcare professionals }\end{array}$ & $\begin{array}{l}\text { Structured and standardized training program to ensure that } \\
\text { healthcare professionals are knowledgeable about available } \\
\text { treatments and can adequately inform people with diabetes }\end{array}$ \\
\hline Lack of available resources & $\begin{array}{l}\text { Development of HTA bodies to better allocate resources and } \\
\text { healthcare expenditure to maximize overall health }\end{array}$ \\
\hline
\end{tabular}

$H T A$ health technology assessment

\section{Overcoming the Access and Funding Barriers}

Improvement or creation, implementation, and development of HTA bodies in Central and Eastern European countries should help to drive more understanding of long-term cost-effectiveness, overcome the focus on short-term cost outcomes, and establish health economic analyses as the basis for reimbursement decisions for any novel medical intervention [84]. In turn, this approach could enable better allocation of limited funding resources towards interventions that promote greater overall health benefits for the population while providing value for money, and thereby increased funding for novel diabetes technologies, should they prove cost-effective. Indeed, a recent cost- effectiveness analysis in the UK showed that an advanced HCL system was associated with cost savings over PwD's lifetimes owing to a reduced incidence of diabetes-related complications [85]. Procurement of biosimilar insulins could also help healthcare authorities in Central and Eastern Europe to save resources and allow funding to be redirected to novel diabetes technologies.

A recent study in Bulgaria has recommended the improvement of the HTA framework and collaboration between healthcare professionals and pharmaceutical structures to encourage a better understanding of diabetes technologies [86]. A focus on long-term analyses should also be particularly pertinent for diabetes interventions, as the majority of expenditure arises from long-term diabetes-related complications, and ADA modeling guidelines for diabetes 
interventions indicate a lifetime time horizon to capture all relevant clinical and cost outcomes $[5,87]$. For novel HCL systems, provision of cost-effectiveness analyses to these existing or nascent HTA authorities can help overcome funding barriers. These analyses should demonstrate the clinical benefits of the intervention in terms of quality of life while providing value for money for the healthcare payer, and can follow similar cost-effectiveness analyses published for other country settings $[85,88,89]$. That acknowledged, short-term studies can still demonstrate utility evidenced by recent real-world data that indicated SAP therapy led to improved HbA1c and quality of life, and reduced fear of hypoglycemia, acute diabetes-related complications, and work absenteeism over both 12 and 24 months $[90,91]$.

Targeting older PwD by expanding the population indications for CSII in Poland and Ukraine (where age limits currently exist) could also increase use of diabetes technologies in populations that could benefit greatly from these devices. Older people with T1D experience an increased risk of severe hypoglycemia (due to a combination of factors including reduced awareness of hypoglycemic warning symptoms and increased response time) and are therefore viable candidates for CGM, SAP, and HCL systems. Expanding coverage of SAP to near full reimbursement for children with diabetes could also prove useful in Slovakia, with an increasing proportion of pediatric individuals diagnosed with T1D, meaning a substantial number of individuals will require almost lifelong treatment and management programs [92]. Moreover, expanding coverage of expert telemedicine to people with T1D living in rural areas could overcome barriers to care should development of nearby, dedicated diabetes centers prove untenable.

\section{Overcoming the Human Barriers}

Improvements in the presentation of novel diabetes technologies can help to overcome potential apathy towards management of T1D. Improving knowledge in PwD of the efficacy of these technologies, which can lower the risk of hypoglycemic events versus MDI, can drive reduced fear of hypoglycemia and subsequently improved adherence, better glycemic control, and improved quality of life $[14-16,21]$. The improved user-friendliness of diabetes technologies should also be emphasized, as these benefits are likely to translate into more intensive usage and, consequently, lower HbA1c values [93]. That acknowledged, the attending physician must also be aware of these benefits so they can accurately inform PwD. Countryspecific, round-table discussion sessions involving healthcare professionals, PwD, healthcare authorities, and state representatives could be arranged to identify the key hesitations to the use of diabetes technologies amongst physicians and PwD, and to better present the clinical benefits of these devices to allay any potential concerns. Moreover, data obtained from diabetes treatment can be analyzed and published to clearly demonstrate the benefits of technologies in real-world practice.

Improving the physical features and appeal of wearable diabetes technologies to younger PwD has been identified as a key factor in driving uptake in pediatric populations, but the panel felt that extolling the benefits of the systems in terms of improved glycemic control and a lower risk of hypoglycemia, as well as reduced burden of managing the disease, should be the focus in this population and that this could overcome other hesitations [78]. Support from peers (as well as advocacy of novel therapies) can also help drive uptake. In all populations, presentation of these technologies should be associated with a structured and standardized training program for people with T1D initiating technology therapy, with co-operation between the physician and patient key.

\section{Overcoming the Healthcare Inefficiency Barriers}

A structured and homogenous training program for physicians can help to standardize care throughout the Central and Eastern European region. Combined with increasing the number of specialized diabetologists in the region- 
through novel training courses, more mobile and regularly operating units in rural areas, and more direct contact between local governments and the International Diabetes Federation (IDF), which may be especially useful in countries with the poorest access to advanced diabetes care-this can lead to improved leadership and organization of departments, thereby driving efficiency in the provision of technological therapies. In turn, this can drive uptake in individuals with T1D as physicians become more knowledgeable of the technologies and their benefits and explain these to their patients. Diabetes teams can promote optimal utilization of devices and support problem solving with patients, helping to improve glycemic control, optimize quality of life, and reduce or prevent device discontinuation $[94,95]$.

\section{Lessons from Prior Position Statements}

A 2021 consensus statement indicated that characteristics of individuals with diabetes can be used to predict successful utilization of CSII [34]. For example, a preferred candidate for CSII would be an individual with high engagement with their diabetes regimen (i.e., highly motivated to achieve optimal blood glucose control yet unable to do so on current therapy). Conversely, individuals who are less motivated by technology, have a history of nonadherence to MDI protocols, or who report substantial reservations about pump usage interfering with lifestyle were not anticipated to be good candidates for CSII. However, psychological factors that can be externally influenced can play a large role in increasing or decreasing patient engagement and expectations; people recognizing that success or failure of therapies are attributable to their own efforts have been reported to engage more effectively with pump use [96]. These characteristics also apply for individuals eligible for HCL systems.

A 2017 international consensus statement recommended the use of CGM alongside a substantial education program, to ensure that individuals have the knowledge to interpret data and use devices appropriately [31]. This aligns with the panel's recommendation of a structured training program on initiation of diabetes technologies, performed by an adequately trained and specialized healthcare professional.

A recent position statement covering several Central and Eastern European countries, including Croatia, Serbia, and Slovenia, indicated the ideal candidate for diabetes technologies as an educated individual with a full understanding of the principles of intensive insulin therapy, motivated to improve glycemic control, without reservations about pump therapy, and with a history of adherence and engagement with diabetes services. Parental supervision is advised for individuals with T1D aged less than 15 years, but CSII should be considered for all PwD who can safety manage the device. Individuals should also undergo periodic evaluation to ensure that CSII treatment is effective. CGM use was endorsed in all individuals with T1D using either CSII or MDI. Emphasis was given to a well-trained, multidisciplinary team for appropriate patient selection and education, via a comprehensive pump and sensor management program. Combination of CSII and CGM in SAP therapy was recommended in both pediatric and adult populations, particularly for individuals experiencing a high risk or fear of hypoglycemia, provided the benefits of the system correlate with adherence.

\section{Recommendations for National and Regional Guidelines}

The panel recommended use of HCL systems in individuals of all ages with T1D with any of the following criteria: diagnosis within the past 6-12 months; previous intensive insulin therapy combined with CGM over a period of 3-6 months; HbA1c values greater than $7.0 \%$ (53 $\mathrm{mmol} / \mathrm{mol})$; TIR less than $70 \%$; clinically relevant or severe hypoglycemia with time below range (TBR) greater than $4.0 \%$; or high glycemic variability. These minimal criteria formed the basis of the updated guidance in several Western countries and Slovenia (Table 3), and the panel expressed a desire to 
extrapolate these guidelines to the entire Central and Eastern European region.

\section{CONCLUSIONS}

The present position statement emphasizes the endeavor of the healthcare community to ensure that individuals with T1D gain access to efficacious technology in a timely and economically responsible manner, thereby improving key health outcomes such as glycemic control and quality of life. Lack of funding to Central and Eastern European healthcare programs was identified as a key barrier to access. Alongside improvements in funding and efficient reallocation of resources, structured education of physicians and PwD should form the basis of implementing diabetes technologies for T1D. Further development of HTA organizations in the region should also help to improve evidence-based reimbursement and implementation of cost-effective measures to improve health outcomes while maximizing healthcare resources and providing value for money for healthcare systems and society overall.

\section{ACKNOWLEDGEMENTS}

Funding. This study and the Journal's Rapid Service were supported by funding from Medtronic International Trading Sàrl, Geneva, Switzerland.

Authorship. All named authors meet the International Committee of Medical Journal Editors (ICMJE) criteria for authorship for this article, take responsibility for the integrity of the work as a whole, and have given their approval for this version to be published.

Author Contributions. All the authors contributed equally and followed the first authorship position.

Medical Writing, Editorial and Other Assistance. Medical writing and editorial support was provided by Ossian Health Economics and Communications $\mathrm{GmbH}$, Basel, Switzerland.

Disclosures. Andrej Janez has served as a consultant and is on speakers' bureaus for AstraZeneca, Boehringer Ingelheim, Eli Lilly, MSD, Novo Nordisk, Abbott, Sanofi, and Medtronic. Tadej Battelino has served on advisory boards for Novo Nordisk, Sanofi, Eli Lilly, Boehringer, Medtronic, Indigo, and DreaMed Diabetes, and received honoraria for participating on the speakers' bureaus of Eli Lilly, Novo Nordisk, Medtronic, Abbott, Sanofi, Aventis, AstraZeneca, and Roche. TB owns stocks of DreamMed Diabetes. TB's institution has received research grant support from Abbott, Medtronic, Novo Nordisk, GluSense, Sanofi, Novartis, Sandoz, and Zealand Pharma. Tomasz Klupa has served on advisory panels for Medtronic, Bioton, Boehringer Ingelheim, Roche, Ascensia, Abbott, Eli Lilly, Sanofi, Ypsomed, and Dexcom, provided research support for Medtronic, and participated in speakers' bureaus for Medtronic, Bioton, Boehringer Ingelheim, Roche, Ascensia, Abbott, Eli Lilly, Sanofi, Novo Nordisk, and Servier. Győző Kocsis has served on advisory boards for Boehringer Ingelheim and Novo Nordisk, and received speaking honoraria, travel and accommodation support from AstraZeneca, Boehringer Ingelheim, Eli Lilly, Medtronic, and Novo Nordisk. GK's institution has received research grant support from Eli Lilly, Medtronic, and Novo Nordisk, and support in training and education of staff members from Medtronic. Miriam Kuricová has served on advisory boards for Eli Lilly and Medtronic and received honoraria for participating on the speakers' bureaus of Eli Lilly, Novo Nordisk, Medtronic, Abbott, Sanofi, Merck, and Pfizer. Nebojša Lalić has served as a lecturer and advisory board member for Medtronic and Roche Diabetes. Anca Pantea Stoian is currently Vice President of the Romanian National Diabetes Committee, and has given lectures, received honoraria and research support, and participated in conferences, advisory boards and clinical trials sponsored by AstraZeneca, Amgen, Boehringer Ingelheim, CocaCola, Medtronic, Eli Lilly, Merck, Novo Nordisk, 
Roche Diagnostics, and Sanofi. Martin Prázný has received consulting and speakers' fees from Abbott, Amgen, AstraZeneca, Boehringer Ingelheim, Eli Lilly, Medtronic, Merck Sharp \& Dohme, Mundipharma, Novo Nordisk, Sanofi, and Teva. Dario Rahelić is the director of the Vuk Vrhovac University Clinic for Diabetes, Endocrinology and Metabolic Diseases at Merkur University Hospital, Zagreb, Croatia and is the president of the Croatian Society for Diabetes and Metabolic Disorders of the Croatian Medical Association. DR serves as an Executive Committee member of the Croatian Endocrine Society, the Croatian Society for Obesity, the Croatian Society for Endocrine Oncology, and the Diabetes and Cardiovascular Disease Study Group of EASD, and has previously served as an Executive Committee member of Diabetes and Nutrition Study Group of EASD. DR was a board member and secretary of IDF Europe and is currently the chair of IDF YLD Programme. DR has served as principal investigator or co-investigator in clinical trials of AstraZeneca, Eli Lilly, MSD, Novo Nordisk, Sanofi Aventis, Solvay, and Trophos, and has received honoraria for speaking or advisory board engagements and consulting fees from Abbott, Amgen, AstraZeneca, Bauerfeund, Bayer, Belupo, Berlin-Chemie, Boehringer Ingelheim, Eli Lilly, Lifescan-Johnson \& Johnson, Novartis, Novo Nordisk, Medtronic, MSD, Merck Sharp \& Dohme, Mylan, Pfizer, Pliva, Roche, Salvus, Sanofi Aventis, and Takeda. Jan Šoupal, has received speaker honoraria and consulted for Abbott, Dexcom, Eli Lilly, Medtronic, Novo Nordisk, and Roche. Tsvetalina Tankova has served on advisory boards of Novo Nordisk, Sanofi, Eli Lilly, Boehringer Ingelheim, AstraZeneca, Medtronic, Novartis, and MSD, and received honoraria for participating on the speakers' bureaus of Eli Lilly, Novo Nordisk, Servier, Sanofi, Boehringer Ingelheim, AstraZeneca, and MSD. Nataliya Zelinska has received speaker honoraria, travel and accommodation support from Medtronic, Berlin-Chemie, ACINO, Novo Nordisk, Pfizer, Sanofi, and Ferring, has served on advisory boards for Novo Nordisk and Medtronic and has served as a consultant for Medtronic.
Compliance with Ethics Guidelines. This article is based on previously conducted studies and does not contain any studies with human participants or animals performed by any of the authors.

Data Availability. Data sharing is not applicable to this article as no datasets were generated or analyzed during the current study.

Open Access. This article is licensed under a Creative Commons Attribution-NonCommercial 4.0 International License, which permits any non-commercial use, sharing, adaptation, distribution and reproduction in any medium or format, as long as you give appropriate credit to the original author(s) and the source, provide a link to the Creative Commons licence, and indicate if changes were made. The images or other third party material in this article are included in the article's Creative Commons licence, unless indicated otherwise in a credit line to the material. If material is not included in the article's Creative Commons licence and your intended use is not permitted by statutory regulation or exceeds the permitted use, you will need to obtain permission directly from the copyright holder. To view a copy of this licence, visit http:// creativecommons.org/licenses/by-nc/4.0/.

\section{REFERENCES}

1. International Diabetes Federation. Diabetes Atlas-9th Edition. 2019. https://diabetesatlas.org/ data/en/world/. Accessed 08 Dec 2020.

2. The Diabetes Control and Complications Trial Research Group. The effect of intensive treatment of diabetes on the development and progression of long-term complications in insulin-dependent diabetes mellitus. N Engl J Med. 1993;329:977-86.

3. Nathan DM. The diabetes control and complications trial/epidemiology of diabetes interventions and complications study at 30 years: overview. Diabetes Care. 2014;37(1):9-16.

4. The DCCT/EDIC Research Group. Intensive diabetes treatment and cardiovascular outcomes in type 1 diabetes: the DCCT/EDIC study 30-year 
follow-up NIH external link. Diabetes Care. 2016;39(5):686-93.

5. Stedman M, Lunt M, Davies M, et al. Cost of hospital treatment of type 1 diabetes (T1DM) and type 2 diabetes (T2DM) compared to the non-diabetes population: a detailed economic evaluation. BMJ Open. 2020;10: e033231.

6. Smith-Palmer J, Bae JP, Boye KS, Norrbacka K, Hunt B, Valentine WJ. Evaluating health-related quality of life in type 1 diabetes: a systematic literature review of utilities for adults with type 1 diabetes. Clinicoecon Outcomes Res. 2016;8:559-71.

7. Nielsen HB, Ovesen LL, Mortensen LH, Lau CJ, Joensen LE. Type 1 diabetes, quality of life, occupational status and education level: a comparative population-based study. Diabetes Res Clin Pract. 2016;121:62-8.

8. Mameli C, Mazzantini S, Nasr MB, Fiorina $\mathrm{P}$, Scaramuzza AE, Zuccotti GV. Explaining the increased mortality in type 1 diabetes. World J Diabetes. 2015;6(7):889-95.

9. Stettler C, Allemann S, Jüni P, et al. Glycemic control and macrovascular disease in types 1 and 2 diabetes mellitus: meta-analysis of randomized trials. Am Heart J. 2006;152(1):27-38.

10. Runge AS, Kennedy L, Brown AS. Does time-inrange matter? Perspectives from people with diabetes on the success of current therapies and the drivers of improved outcomes. Clin Diabetes. 2018;36(2):112-9.

11. López-Bastida J, López-Siguero JP, Oliva-Moreno J, et al. Social economic costs of type 1 diabetes mellitus in pediatric patients in Spain: CHRYSTAL observational study. Diabetes Res Clin Pract. 2017;127:59-69.

12. Bogdanović R. Diabetic nephropathy in children and adolescents. Pediatr Nephrol. 2008;23(4): 507-25.

13. McKnight JA, Wild SH, Lamb MJE, et al. Glycaemic control of type 1 diabetes in clinical practice early in the 21st century: an international comparison. Diabet Med. 2015;32(8):1036-50.

14. McCrimmon RJ, Frier BM. Hypoglycaemia, the most feared complication of insulin therapy. Diabetes Metab. 1994;20(6):503-12.

15. McCrimmon RJ, Frier BM, Deary IJ. Appraisal of mood and personality during hypoglycaemia in human subjects. Physiol Behav. 1999;67(1):27-33.

16. McCrimmon RJ, Sherwin RS. Hypoglycemia in type 1 diabetes. Diabetes. 2010;59(10):2333-9.
17. Martín-Timón I, del Cañizo-Gómez FJ. Mechanisms of hypoglycemia unawareness and implications in diabetic patients. World J Diabetes. 2015;6(7): 912-26.

18. Czyzewska K, Czerniawska E, Szadkowska A. Prevalence of hypoglycemia unawareness in patients with type 1 diabetes. Pediatr Diabet. 2012;13(Suppl 17):77.

19. Choudhary P, Geddes J, Freeman JV, Emery CJ, Heller SR, Frier BM. Frequency of biochemical hypoglycaemia in adults with type 1 diabetes with and without impaired awareness of hypoglycaemia: no identifiable differences using continuous glucose monitoring. Diabetes Med. 2010;27(6):666-72.

20. Gold AE, MacLeod KM, Frier BM. Frequency of severe hypoglycemia in patients with type I diabetes with impaired awareness of hypoglycemia. Diabetes Care. 1994;17(7):697-703.

21. Fidler C, Christensen TE, Gillard S. Hypoglycemia: an overview of fear of hypoglycemia, quality-of-life, and impact on costs. J Med Econ. 2011;14(5): 646-55.

22. Kadish AH. Automation control of blood sugar a servomechanism for glucose monitoring and control. Trans Am Soc Artif Intern Organs. 1963;9: 363-7.

23. Burckhardt M-A, Smith GJ, Cooper MN, Jones TW, Davis EA. Real-world outcomes of insulin pump compared to injection therapy in a populationbased sample of children with type 1 diabetes. Pediatr Diabetes. 2018;19(8):1459-66.

24. Moreno-Ferández J, García-Seco JA, Herrera-Moraleda $M$, Seco AM, Muñoz-Rodríguez JR. Realworld outcomes of insulin pump compared to multiple daily injection therapy in adult type 1 diabetes mellitus patients in a Mediterranean scenario. Int J Diabetes Dev Ctries. 2020. https://doi. org/10.1007/s13410-020-00887-4.

25. McGill JB, Ahmann A. Continuous glucose monitoring with multiple daily insulin treatment: outcome studies. Diabetes Technol Ther. 2017;19(Suppl 3):S3-12.

26. Ahmadi SS, Westman K, Pivodic A, et al. The association between HbA1c and time in hypoglycemia during CGM and self-monitoring of blood glucose in people with type 1 diabetes and multiple daily insulin injections: a randomized clinical trial (GOLD-4). Diabetes Care. 2020;43(9):2017-24.

27. Beck RW, Riddlesworth T, Ruedy K, et al. Effect of continuous glucose monitoring on glycemic control in adults with type 1 diabetes using insulin 
injections: the DIAMOND randomized clinical trial. JAMA. 2017;317(4):371-8.

28. Hirsch IB, Bode BW, Garg S, et al. Continuous subcutaneous insulin infusion (CSII) of insulin aspart versus multiple daily injection of insulin aspart/insulin glargine in type 1 diabetic patients previously treated with CSII. Diabetes Care. 2005;28(3):533-8.

29. National Institute for Health and Care Excellence (NICE). Type 1 diabetes in adults: diagnosis and management-NICE guideline [NG17]. 2020. https://www.nice.org.uk/guidance/ng17. Accessed 01 Feb 2021.

30. Peters AL, Ahmann AJ, Hirsch IB, Raymond JK. Advances in glucose monitoring and automated insulin delivery: supplement to Endocrine Society clinical practice guidelines. $\mathrm{J}$ Endocr Soc. 2018;2(11):1214-25.

31. Danne T, Nimri R, Battelino $\mathrm{T}$, et al. International consensus on use of continuous glucose monitoring. Diabetes Care. 2017;40(12):1631-40.

32. Hoogma RPLM, Hammond PJ, Gomis R, et al. Comparison of the effects of continuous subcutaneous insulin infusion (CSII) and NPH-based multiple daily insulin injections (MDI) on glycaemic control and quality of life: results of the 5-nations trial. Diabet Med. 2006;23(2):141-7.

33. American Diabetes Association. 7. Diabetes technology: standards of medical care in diabetes2021. Diabetes Care. 2021;44(Suppl. 1):S85-99.

34. Grunberger G, Sherr J, Allende M, et al. American Association of Clinical Endocrinology clinical practice guideline: the use of advanced technology in the management of persons with diabetes mellitus. Endocr Pract. 2021;27(6):505-37.

35. Peters AL, Ahmann AJ, Battelino T, et al. Diabetes technology-continuous subcutaneous insulin infusion therapy and continuous glucose monitoring in adults: an Endocrine Society clinical practice guideline. J Clin Endocrinol Metab. 2016;101(11): 3922-37.

36. Cohen O, Vigersky RA, Lee SW, Cordero TL, Kaufman FR. Letter to the editor: automated insulin delivery system nomenclature. Diabetes Technol Ther. 2017;19(6):379-80.

37. Steineck I, Ranjan A, Nørgaard K, Schmidt S. Sensoraugmented insulin pumps and hypoglycemia prevention in type 1 diabetes. J Diabetes Sci Technol. 2017;11(1):50-8.

38. Zucchini S, Scipione M, Balsamo C, et al. Comparison between sensor-augmented insulin therapy with continuous subcutaneous insulin infusion or multiple daily injections in everyday life: 3-day analysis of glucose patterns and sensor accuracy in children. Diabetes Technol Ther. 2011;13(12): 1187-93.

39. Bosi E, Choudhary P, de Valk HW, et al. Efficacy and safety of suspend-before-low insulin pump technology in hypoglycaemia-prone adults with type 1 diabetes (SMILE): an open-label randomised controlled trial. Lancet Diabetes Endocrinol. 2019;7: 462-72.

40. Cherubini V, Gesuita R, Skrami E, et al. Optimal predictive low glucose management settings during physical exercise in adolescents with type 1 diabetes. Pediatr Diabetes. 2019;20(1):107-12.

41. Klupa T, Hohendorff J, Benbenek-Klupa T, Matejko B, Malecki MT. Insulin pump settings and glucose patterns during a 1008-km non-stop bicycle race in a patient with type 1 diabetes mellitus. Acta Diabetol. 2019;56:593-5.

42. Abraham MB, Nicholas JA, Smith GJ, et al. Reduction in hypoglycemia with the predictive low-glucose management system: a long-term randomized controlled trial in adolescents with type 1 diabetes. Diabetes Care. 2018;41(2):303-10.

43. Forlenza GP, Li Z, Buckingham BA, et al. Predictive low-glucose suspend reduces hypoglycemia in adults, adolescents, and children with type 1 diabetes in an at-home randomized crossover study: results of the PROLOG trial. Diabetes Care. 2018;41: dc180771.

44. Sharifi A, De Bock MI, Jayawardene D, et al. Glycemia, treatment satisfaction, cognition, and sleep quality in adults and adolescents with type 1 diabetes when using a closed-loop system overnight versus sensor-augmented pump with low-glucose suspend function: a randomized crossover study. Diabetes Technol Ther. 2016;18:772-83.

45. Tauschmann M, Thabit H, Bally L, et al. Closedloop insulin delivery in suboptimally controlled type 1 diabetes: a multicentre, 12-week randomised trial. Lancet. 2018;392:1321-9.

46. Bally L, Thabit H, Kojzar H, et al. Day-and-night glycaemic control with closed-loop insulin delivery versus conventional insulin pump therapy in freeliving adults with well controlled type 1 diabetes: an open-label, randomised, crossover study. Lancet Diabetes Endocrinol. 2017;5:261-70.

47. Garg SK, Weinzimer SA, Tamborlane WV, et al. Glucose outcomes with the in-home use of a hybrid closed-loop insulin delivery system in adolescents and adults with type 1 diabetes. Diabetes Technol Ther. 2017;19(3):155-63. 
48. Brown SA, Kovatchev BP, Raghinaru D, et al. Sixmonth randomized, multicenter trial of closed-loop control in type 1 diabetes. $\mathrm{N}$ Engl J Med. 2019;381(18):1707-17.

49. Medtronic. Press release: Medtronic Presents U.S. Pivotal Trial Data for MiniMed ${ }^{\mathrm{TM}} 780 \mathrm{G}$ Advanced Hybrid Closed Loop System with Automated Correction Bolus Feature. 2020. https://newsroom. medtronic.com/news-releases/news-release-details/ medtronic-presents-us-pivotal-trial-data-

minimedtm-780g-advanced. Accessed 23 Feb 2021.

50. Barnard KD, Wysocki T, Ully V, et al. Closing the loop in adults, children and adolescents with suboptimally controlled type 1 diabetes under free living conditions: a psychosocial substudy. J Diabetes Sci Technol. 2017;11:1080-8.

51. Heinemann L, DeVries JH. Reimbursement for continuous glucose monitoring. Diabetes Technol Ther. 2016;18(Suppl 2):S248-52.

52. Khunti K, Cigrovski Berković M, Ludvik B, et al. Regional variations in definitions and rates of hypoglycaemia: findings from the global HAT observational study of 27585 people with type 1 and insulin-treated type 2 diabetes mellitus. Diabetes Med. 2018;35(9):1232-41.

53. Tauschmann M, Hermann JM, Freiberg C, et al. Reduction in diabetic ketoacidosis and severe hypoglycemia in pediatric type 1 diabetes during the first year of continuous glucose monitoring: a multicenter analysis of 3553 subjects from the DPV registry. Diabetes Care. 2020;43: dc191358.

54. DeSalvo DJ, Miller KM, Hermann JM, et al. Continuous glucose monitoring and glycemic control among youth with type 1 diabetes: International comparison from the T1D Exchange and DPV Initiative. Pediatr Diabetes. 2018;19(7):1271-5.

55. Национална Здравноосигурителна Каса [Bulgarian National Health Insurance Fund]. Изисквания на НЗОК за предписване на медицински изделия за приложение с инсулинови помпи при захарен диабет тип 1 в извьнболничната помош [Requirements of the National Health Insurance Fund for prescribing medical devices for use with insulin pumps in type 1 diabetes mellitus in outpatient care]. 2020. https://www.nhif.bg/page/207. Accessed 23 Feb 2021.

56. Hrvatski zavod za zdravstveno osiguranje [Croatian Health Insurance Fund]. Medicinski proizvodi [Medical products]. Osnovna lista pomagala [List of reimbursed diabetes medical devices in Croatia]. $2020 . \quad$ https://hzzo.hr/zdravstvena-zastita/ medicinski-proizvodi. Accessed 23 Feb 2021.
57. Státní ústav pro kontrolu léčiv [Czech State Institute for Drug Control]. Seznam zdravotnických prostředků hrazených na poukaz [List of reimbursed medical devices]. 2021. https://www.sukl.cz/sukl/ seznam-zdravotnickych-prostredku-hrazenych-napoukaz. Accessed 23 Feb 2021.

58. Nemzeti Egészségbiztosítási Alapkezelő [Hungarian National Health Insurance Fund]. Végleges publikus gyógyászatisegédeszköz-törzs [Final public medical device list]. 2020. http://neak.gov.hu/felso_menu/ szakmai_oldalak/gyogyszer_segedeszkoz_ gyogyfurdo_tamogatas/egeszsegugyi_ vallalkozasoknak/puphag/Vegleges_PUPHAG.html. Accessed 23 Feb 2021.

59. Narodowy Fundusz Zdrowia [Polish National Health Fund]. Załączniki do zarządzenia Prezesa NFZ, z dnia 29 listopada 2019 r. Nr 167/2019/DSOZ [Attachments to the order of the President of the National Health Fund of November 29, 2019 No. 167/2019 / DSOZ]. Katalog zakresów w rodzaju świadczenia zdrowotne kontraktowane odrębnie [Catalogue of contracted health services]. 2019. http://sipdata.lex.pl/dane/urzedowe/2019/ 2294786/1.pdf?_ga=2.100035097.626621916. 1611055805-1360556567.1611055805. Accessed 23 Feb 2021.

60. Narodowy Fundusz Zdrowia [Polish National Health Fund]. w sprawie ogłoszenia jednolitego tekstu rozporzadzenia Ministra Zdrowia w sprawie wykazu wyrobów medycznych [Regulation of medical devices]. 2019. http://isap.sejm.gov.pl/ isap.nsf/download.xsp/WDU20190001267/O/ D20191267.pdf. Accessed 23 Feb 2021.

61. Casa Naţională de Asigurări de Sănătate [Romanian National Health Insurance House]. Programul naţional de diabet zaharat [National Diabetes Program]. 2021. http://www.cnas.ro/page/programulnational-de-diabet-zaharat.html. Accessed 23 Feb 2021.

62. Републички фонд за здравствено осигурае [Serbian Public Health Insurance Fund]. ЛИСТА ПОМАГАЛА [Help list]. 2021. https://www.rfzo.rs/ download/pravilnici/pomagala/Lista\%20pomagala. pdf. Accessed 23 Feb 2021.

63. Републички фонд за здравствено осигурае [Serbian Public Health Insurance Fund]. Највиши износи накнада за одреена медицинско-техничка помагала која се издају преко апотеке [Highest fees for medical devices issued through pharmacies]. 2021. https://www.rfzo.rs/download/pravilnici/ pomagala/Prilog\%20o\%20naknadi\%20troskova $\%$ 20MTP\%201.pdf. Accessed 23 Feb 2021.

64. Републички фонд за здравствено осигурае [Serbian Public Health Insurance Fund]. Највиши износи накнада за медицинско-техничка помагала која се 
обезбеују из средстава обавезног здравственог осигураа преко испоручилаца помагала [Highest fees for medical devices issued through mandatory health insurance]. 2021. https://www.rfzo.rs/ download/pravilnici/pomagala/Prilog\%202. izmena.pdf. Accessed 23 Feb 2021.

65. Ministerstvo Zdravotníctva Slovenskej Republiky [Ministry of Health of the Slovak Republic]. Zoznam kategorizovaných zdravotníckych pomôcok [List of categorized medical devices]. 2021. https://www. health.gov.sk/?zoznam-kategorizovanychzdravotnickych-pomocok. Accessed 23 Feb 2021.

66. Zavod za zdravstveno zavarovanje Slovenije [Health Insurance Institute of Slovenia]. Elektronska Gradiva [Electronic materials]. Seznam medicinskih pripomočkov s šifrantom, medicinskimi kriteriji, pooblastili, postopki in cenovnimi standardi [List of medical devices with code list, medical criteria, authorizations, procedures and pricing]. 2021. https://www.zzzs.si/?id=126\&detail= DFDC914987E44E2AC1257353003EC73A. Accessed 12 July 2021.

67. Jakovljevic MB. Resource allocation strategies in Southeastern European health policy. Eur J Health Econ. 2013;14:153-9.

68. Kaló Z, Gheorghe A, Huic M, Csanádi M, Kristensen FB. HTA implementation roadmap in Central and Eastern European countries. Health Econ. 2016;25: 179-92.

69. Huic M, Hacek RT, Svajger I. Health technology assessment in Central, Eastern, and South European countries: Croatia. Int J Technol Assess Health Care. 2017;33(3):376-83.

70. Atanasijevic D, Zah V. Health technology assessment in Serbia. Int J Technol Assess Health Care. 2017;33(3):384-9.

71. Csanádi $\mathrm{M}$, Inotai $\mathrm{A}$, Oleshchuk $\mathrm{O}$, et al. Health technology assessment implementation in Ukraine: current status and future perspectives. Int J Tech Assess Health Care. 2019;35(5):393-400.

72. Rais C, Kaló Z, Csanádi M, Negulescu V. Current and future perspectives for the implementation of health technology assessment in Romania. Health Policy Technol. 2020;9(1):45-52.

73. Malinowski KP, Kawalec P, Trąbka W, et al. Health technology assessment and reimbursement policy for oncology orphan drugs in Central and Eastern Europe. Orphanet J Rare Dis. 2020;15:277.

74. Godman B, Hill A, Simoens S, et al. Potential approaches for the pricing of cancer medicines across Europe to enhance the sustainability of healthcare systems and the implications. Expert
Rev Pharmacoecon Outcomes Res. 2021;21(4): 527-40.

75. Cohen D. Cancer drugs: high price, uncertain value. BMJ. 2017;359: j4543.

76. Luzzatto L, Hyry HI, Schieppati A, et al. Outrageous prices of orphan drugs: a call for collaboration. Lancet. 2018;392:791-4.

77. Németh B, Goettsch W, Kristensen FB, et al. The transferability of health technology assessment the European perspective with focus on central and Eastern European countries. Exp Rev Pharmacoecon Outcomes Res. 2020;20(4):321-30.

78. Stumetz KS, Yi-Frazier JP, Mitrovich C, Early KB. Quality of care in rural youth with type 1 diabetes: a cross-sectional pilot assessment. BMJ Open Diabetes Res Care. 2016;4: e000300.

79. Massey CN, Appel SJ, Buchanan KL, Cherrington AL. Improving diabetes care in rural communities: an overview of current initiatives and a call for renewed efforts. Clin Diabetes. 2010;28(1):20-7.

80. Padala PR, Desouza CV, Almeida S, et al. The impact of apathy on glycemic control in diabetes: a crosssectional study. Diabetes Res Clin Pract. 2008;79: $37-41$.

81. Vaportzis E, Clausen MG, Gow AJ. Older adults perceptions of technology and barriers to interacting with tablet computers: a focus group study. Front Psychol. 2017;8:1687.

82. Tanenbaum ML, Hanes SJ, Miller KM, Naranjo D, Bensen R, Hood KK. Diabetes device use in adults with type 1 diabetes: barriers to uptake and potential intervention targets. Diabetes Care. 2017;40: $181-7$.

83. Doničová V, Brož J, Sorin I. Health care provision for people with diabetes and postgraduate training of diabetes specialists in Eastern European countries. J Diabetes Sci Technol. 2011;5(5):1124-36.

84. Current status of health intervention and technology assessment in the Balkan region. Copenhagen: WHO Regional Office for Europe. 2020. https:// apps.who.int/iris/bitstream/handle/10665/336228/ WHO-EURO-2020-1303-41053-55733-eng.pdf. Accessed 01 Feb 2021.

85. Roze S, Buompensiere MI, Ozdemir Z, de Portu S, Cohen O. Cost-effectiveness of a novel hybrid closed-loop system compared with continuous subcutaneous insulin infusion in people with type 1 diabetes in the UK. J Med Econ. 2021;24: 883-90. 
86. Tsanova DK, Grancharova GG, Aleksandrova-Yankulovska SS, Vekov TJ. Diabetes in Bulgaria and the need for health technology assessment. Public Health. 2017;21:11-5.

87. American Diabetes Association Consensus Panel. Guidelines for computer modeling of diabetes and its complications. Diabetes Care. 2004;27(9): 2262-5.

88. Jendle J, Pöhlmann J, de Portu S, Smith-Palmer J, Roze S. Cost-effectiveness analysis of the MiniMed 670G hybrid closed-loop system versus continuous subcutaneous insulin infusion for treatment of type 1 diabetes. Diabetes Technol Ther. 2019;21(3): $110-8$.

89. Pease A, Zomer E, Liew D, et al. Cost-effectiveness analysis of a hybrid closed-loop system versus multiple daily injections and capillary glucose testing for adults with type 1 diabetes. Diabetes Technol Ther. 2020;22(11):812-21.

90. Charleer S, Mathieu C, Nobels F, et al. Effect of continuous glucose monitoring on glycemic control, acute admissions, and quality of life: a realworld study. J Clin Endocrinol Metab. 2018;103(3): 1224-32.
91. Charleer S, De Block C, Nobels F, et al. Sustained impact of real-time continuous glucose monitoring in adults with type 1 diabetes on insulin pump therapy: results after the 24-month RESCUE study. Diabetes Care. 2020;43(12):3016-23.

92. Podolakova K, Jancova BE, Stanik J, Podracka L. Increasing incidence of type 1 diabetes mellitus in young children in Slovakia. Bratislava Med J. 2020;121(2):129-32.

93. Pickup JC, Freeman SC, Sutton AJ. Glycaemic control in type 1 diabetes during real time continuous glucose monitoring compared with self monitoring of blood glucose: meta-analysis of randomised controlled trials using individual patient data. BMJ. 2011;343: d3805.

94. Seereiner S, Neeser K, Weber C, et al. Attitudes towards insulin pump therapy among adolescents and young people. Diabetes Technol Ther. 2010;12: 89-94.

95. Scheiner G, Sobel RJ, Smith DE, et al. Insulin pump therapy guidelines for successful outcomes. Diabetes Educ. 2009;35:S29-41.

96. Liberman A, Barnard K. Diabetes technology and the human factor. Diabetes Technol Ther. 2018;20(Suppl 1):S128-38. 